\title{
EVALUATING THE VETERINARIAN ROLE IN ONE HEALTH APPROACH AT ANTIMICROBIAL RESISTANCE PERSPECTIVES, JORDAN
}

\author{
Szerzők: \\ Randa Ahmad Bazzi (DVM, MPH) \\ University of Debrecen \\ Alaboudi Akram (DVM, MSc,PhD) \\ Jordan University of Science and \\ Technology \\ Gábor Rácz (MD, MPH, PhD) \\ University of Debrecen \\ Első szerző e-mail címe: \\ randaalali12@outlook.com
}

\author{
Lektorok: \\ Ferenc Mező (Ph.D.) \\ Eszterházy Károly Katolikus Egyetem \\ Katalin Mező (Ph.D.) \\ Debreceni Egyetem
}

...és további két anonim lektor

\begin{abstract}
Absztrakt
AZ ÁLLATORVOSI SZEREP ÉRTÉKELÉSE 'ONE HEALTH' MEGKÖZELÍTÉSBEN AZ ANTIMIKROBALIS REZISZTENCIA SZEMPONTJÁBÓL - JORDÁNIA

$\mathrm{Az}$ antimikrobiális szereket világszerte széles körben használják a humán- és állatgyógyászatban betegségek leküzdésére és megelőzésére. A nem hatékony vagy elhúzódó antimikrobiális kezelés következtében a mikrobák rezisztenssé válhatnak, ami közegészségügyi és társadalmi-gazdasági veszélyt jelent, mivel a környezeten és az élelmiszereken keresztül emberre kerül. Az antimikrobiális rezisztencia (AMR) lehetséges egészségügyi problémáinak kezelése érdekében a WHO együttmúködött az OIE-vel és a FOA-val a globális cselekvési terv végrehajtásában, és sürgette a tagországokat, hogy dolgozzanak ki nemzeti tervet az AMR elleni küzdelem minden vonatkozásában. A jordániai egészségügyi minisztérium elkészítette az AMR elleni küzdelem nemzeti tervet (2018-2022), amelyben a MOA és a JVA kulcsfontosságú szerepet tölt be az állat-egészségügyi ágazatban a tervstratégiákba való beavatkozásban. A tanulmány célja, hogy értékelje a jordán állatorvos tudásának, attitűdjének és gyakorlatának szerepét az AMR kezelésében, valamint kiterjedjen a 2017-2020 között regisztrált állatgyógyászati készítményekre is. Egy web alapú keresztmetszeti KAP felmérés linkjét osztották ki a JAV-ban regisztrált állatorvosnak. A bejegyzett gyógyszerkészítményekről szóló jelentéseket a JAV-tól szerezték be, majd az importált és előállított gyógyszerek szerint csoportosították. Az eredményeket leíró jelleggel elemezve kimutatták, hogy az AMR definícióra utaló állítással egyetértő résztvevő átlagos tudása 84\% volt. A többség (95,65\%) az antimikrobiális rezisztenciát
\end{abstract}


a jordániai állat-egészségügyi ágazat kihívásának tekinti, és más zoonózisos betegségek mellett prioritást kell élvezni. A résztvevők 68,70\%-a úgy gondolja, hogy az antimikrobiális szerrel való visszaélés és túlzott mértékű kábítószer, csaló és jogosulatlan gyakorlók okozzák az AMRkihívást, közülük a leggyakoribb gyakorlat az ügyfelek (gazdálkodók, tulajdonosok stb.) ajánlása volt. a jó állattartás gyakorlása (80,00\%). Összefoglalva, az antimikrobiális rezisztencia folyamatos oktatási program végrehajtása elengedhetetlen az állatorvosi ismeretek fejlesztéséhez az AMR minden vonatkozásában; tanácsadói képességeik fejlesztésére. Olyan jogszabályok kötelezővé tétele is, amelyek biztosítják az állatorvos számára a megfelelő antimikrobiális szerek felírását, valamint a felügyeleti rendszer fejlesztése az állategészségügyi területen az antimikrobiális fogyasztás ellenôrzésére.

Kulcsszavak: antimikrobiális rezisztencia, állatorvosok, ismeretek, gyakorlatok, attitűdök, Jordánia

Diszciplínák: állatgyógyászat

\section{Abstract}

Antimicrobials are widely used in human and veterinary medicine around the world for disease control and prevention. Due to inefficient or prolonged antimicrobial treatment, the microbes may become resistant, which will pose public health and socioeconomic threat, as it is transmitted to humans through the environment and food products. To address the potential health of AMR, WHO collaborated with OIE and FOA to implement the Global Action Plan and urged the member countries to develop a national plan, to combat AMR in all aspects. The Ministry of Health in Jordan has conducted the national plan for combatting AMR (2018-2022), in which the MOA and JVA play a critical role as stakeholders for intervening the plan strategies in animal health sector. This study aims to evaluate the role of the Jordanian veterinarian's knowledge, attitudes, and practices in tackling AMR, as well as it will include the registered veterinary pharmaceutical products between 2017-2020. A web based cross-sectional KAP survey link was distributed to the veterinarian who is registered in the JAV. Reports of the registered pharmaceutical products were obtained from JAV and then categorized into imported and produced drugs. The results were analysed descriptively and showed that the average knowledge of the participant who had agreed with the statement that refers to the AMR definition was $84 \%$. The majority $(95.65 \%)$ considered AMR as a challenge for the veterinary sector in Jordan and should be prioritized beside other zoonotic diseases. A $68.70 \%$ of the participants believe that the misuse and overuse of antimicrobial by quacks, fraudulent and unauthorized practitioners are the main contributor to the AMR challenge, and the most common practices among them were recommending the customers (farmers, owner, etc..) to practice good animal husbandries $(80.00 \%)$. To conclude, implementing antimicrobial resistance continual educational program is essential to improve the veterinarian knowledge in all aspects 
of AMR; to enhance their advisory skills. Also obligating legislations that ensure the veterinarian to prescribe the correct antimicrobials and improving the surveillance system to monitor the antimicrobial consumption in the veterinary field.

Keywords: antimicrobial resistance, veterinarians, knowledge, practices, attitudes, Jordan.

Disciplines: veterinary medicine

Randa Ahmad Bazzi, Akram Alaboudi \& Gábor Rácz (2021): Evaluating the Veterinarian Role in One Health Approach at Antimicrobial Resistance Perspectives, Jordan. Lélektan és hadviselés - interdiszciplináris folyóirat, III. évf. 2021/2. szám. 21-54. doi: 10.35404/LH.2021.2.21

Antimicrobials, include antibiotics, antivirals, antifungals, and antiparasitic drugs, are medicines used to prevent and treat infections in humans, animals, and plants (WHO, 2020). Microbes will become antimicrobial-resistant because of ineffective or prolonged antimicrobial treatment (AMR). This trait may be 'innate' due to a slow and long evolutionary process performed by microorganisms to adapt to changing environmental conditions. This adaptation relies on the bacterial cell's impermeability to antibiotic molecules; or acquired due to a 'rapid' adaptation to a sudden selective pressure represented by antimicrobial treatment (Palma et al., 2020). Bacteria becoming resistant to most antimicrobials they are often referred to as 'superbugs' (WHO, n.d.).

Antimicrobials are widely used in human and veterinary medicine around the world for disease control and prevention. (EMA, 2009). Antimicrobials also have been used as growth promoters in food animals since 1950, with subtherapeutic doses enhancing animal growth and feed efficiency while reducing mortality. Due to the addition of streptomycin as a growth promoter in 1951, three strains of streptomycin-resistant coliform bacteria emerged (Starr and Reynolds, 1951). This developed as bacterial evolutionary machinery uses their genomic flexibility to better suit the surrounding environment including the ability to protect themselves from toxic substances (Palma E et al., 2020). Even though antimicrobial chemotherapy is critical for treating and preventing animal diseases, banning it's use in animals will devastate the livestock industry, increase zoonotic bacterial diseases, and have a disastrous impact on animal welfare (McKellar, 1998).The AMR is both lethal and costly and according to current estimates, AMR now kills around 700,000 people a year around the world. By 2050, this figure is expected to reach ten million. Most of these deaths will take place in developing countries (WHO, 2018).

The ARBs of animal origin besides being transmitted to humans through the environ- 
ment and food products they may interact with agricultural workers through direct contact (Van Boeckel et al., 2015). The complex network of interactions occurring between microbial specimens from diverse "environments" facilitates the gene flow, expanding the AMR between humans, animals, and the environment, resulting in an overall hard issue (Palma E et al., 2020).The environmental factors may cause even more the spread of AMR than their use, especially in developing nations with limited access to clean water, poor sanitation, and rudimentary waste management (WHO, 2020).

The risk of antimicrobial resistance transmission could be greatly reduced through strict hygiene measures in abattoirs, markets or food processing plants, as well as pasteurization, heating, and irradiation of animal-derived foods (McKellar, 1998).

AMR is a global health and development threat and it was expected that between 2010 and 2030, the global consumption of antimicrobials will rise by $67 \%$, from $63,151 \pm$ 1,560 tons to $105,596 \pm 3,605$ tons (Van Boeckel et al., 2015).

The response to AMR potential effect on health, food security and economy, has been spearheaded through the One Health Global Action Plan, developed by WHO in collaboration with the Food and Agriculture Organization of the United Nations (FAO) and the World Organization for Animal Health (OIE) (WHO, 2018). This may be defined by 5 main objectives: improve awareness and understanding of AMR communication, education, and training; strengthen the knowledge and evidence base through surveillance and research; reduce the incidence of infection through effective sanitation, hygiene and infection prevention measures; optimize the use of antimicrobial medicines in human and animal health and develop the economic case for sustainable investment that takes account of the needs of all countries, and increase investment in new medicines, diagnostic tools, vaccines and other interventions (WHO, 2018).

It is logical to take a One Health approach when addressing AMR issue (McEwen and Collignon, 2018). In 2015, WHO urged member countries to have their own National Action Plan to combatting AMR (WHO, 2018). The Ministry of Health in Jordan, which is a country member in both WHO and OIE(WHO, n.d.; OIE, n.d.), has conducted the national plan for combatting AMR (20182022), which is a multi-sectoral working group or coordination committee on AMR, established with Government leadership

This study has been conducted to evaluate the role of the Jordanian veterinarians in combat and tackling AMR from all sectors by assessing their knowledge level, attitudes, and their common practices. A well as a list of the sold antimicrobials to identify possible risk factors that may lead to the development and spread of antimicrobial resistance in foodproducing animals.

\section{Method}

\section{Study Area}

The Hashemite Kingdom of Jordan is a country in the Middle East, which is bordered by the Gulf of Aqaba, West Bank to the west, 
Syria to the north, and Saudi Arabia and Iraq to the east (Jordan Map and Satellite Image, 2008). It has a population of about 10.7 million, 6.2 million of the population ages between 15 and 64 years, with 98.2\% literacy rate for adults who are more than 15 years old (FOA, 2016). The agricultural land occupies 1065.96 thousand hectares of the kingdom (FAOSTAT, 2020), and the climate is characterized by warm, dry summers and mild, wet winters, with annual average temperatures ranging from 12 to $25 \mathrm{C}$ and summertime highs reaching the $40 \mathrm{C}$ in the desert regions (UNFPA, 2021). Rainfall averages vary from $50 \mathrm{~mm}$ annually in the desert to $800 \mathrm{~mm}$ in the northern hills, some of which fall as snow, with environmental issues include deforestation, overgrazing, soil erosion, and desertification (FAOSTAT, 2020). In addition to that, it has limited natural freshwater resources (Jordan Map and Satellite Image, 2008). All these factors reflected on the overall percentage of employment in the agriculture sector, which has been decreased around $2 \%$ within the last 20 years, from $4.8 \%$ in 1991 to $3.1 \%$ in 2019 . The agriculture sector takes place in the northern and western highlands, and the most productive areas are in the Jordan Valley. It is composed of livestock (55\%) and crops (45\%), with sheep and goats being the most important livestock breeds in Jordan (FAOSTAT, 2020).

\section{Study population}

This study is designed to evaluate veterinarians' roles in Jordan. To earn a degree in veterinary medicine and surgery, the lonely faculty is located at the Jordan University of
Science and Technology (JUST), which is an active member of the Scientific Association of Arab Veterinary Medical Colleges and is housing its general secretariat (JUST, 2021). To earn a license in Veterinary medicine, the graduate must be a member of the Jordanian Veterinarian Association (JVA), which was established in 1972. JVA has reported that their total members are 1778 veterinarians, 647 of them are employed in the private sector, either in the private clinic or companies. In the public sector, most of the veterinarians are employed in the MOA (146 veterinarians), while the remaining are employed in the MOH; Jordanian Food and Drug Administration; Military, and Municipalities. Only 30 veterinarians are unemployed, and 279 are residing abroad ( JVA, n. d.).

\section{Study design and sample size}

This study aim is to evaluate the role of the knowledge, attitudes, and practices (KAP) of the veterinarian in Jordan, as well as to illustrate the percentage of the registered veterinary pharmaceutical drugs in Jordan.

Regarding the evaluation of the knowledge, attitudes, and practices (KAP), a crosssectional; questionnaire web-based survey was designed. Its questions were based on respective research related to the role of veterinarians in tackling AMR. The survey included 25 questions and was conducted in Arabic and English and reviewed by two academic professionals and one veterinarian. Ethical approval was not required since animals and patients were not included. It consisted of close-end questions, Likert scale statements, an open-ended question, and was 
administered via a Google ${ }^{\circledR}$ form. Due to the pandemic situation, the link of the form was sent electronically (online) to randomly selected veterinarians. It was sent via email to 26 veterinarians, while 67 veterinarians have received it as a message via LinkedIn $\AA$, and 196 veterinarians have received it via Messenger ${ }^{\circledR}$.

The recruited sample size of this study is 215. Rasoft ${ }^{\circledR}$ application was used to calculate it, by submitting the total number of the registered veterinarian, which is 1649 after excluding the dead, with confidence 95\% degree of confidence and $5 \%$ as an acceptable rate of error.

The respondent participants are 119, four of them did not complete the survey and were excluded from the study, only 115 participants were included. The response rate is $41.2 \%$, the assumed low response rate is either due to low internet access or their inactive status in social media. The survey was made available between the 23 of October 2020 and the 13 of November 2020.

Due to the lack of reliable data regarding the percentage of the registered veterinary antimicrobial pharmaceutical drugs, and their importance in supporting these study findings. The annual reports of the registered and re-registered veterinary pharmaceutical drugs between 2017 and 2020 were obtained directly from the Jordanian Veterinarian Association (JVA) and then categorized into imported and produced veterinary drugs, and then subcategorized according to their chemical classification. An exception was made for the antibiotics, they were subcategorized according to the route of administration into parenteral(injection), oral (powder; liquid; suspension; tablet; solution and drench), and intramammary. Although vaccines play an important role in biosecurity, they were not included.

\section{Data Analysis}

The collected results were coded; entered and analysed using XLSTAT ${ }^{\circledR}$ Software 2021. The data were divided into four sections: Demographics, Knowledge, Practice, and Attitudes., and then examined descriptively. To evaluate the veterinarian knowledge, the following scoring system was used: agree; neutral and disagree. While assessing their practices, they were asked to choose the best indicator that reflects their practices, from one /(never) to five (always). As for the attitudes, they were asked to order the most important challenge that they face ascending while tackling AMR, the score was from one (least important) to four (most important). Following that, a bivariant analysis was performed using Pearson's Chi-square, to assess the relationship between one of the practices outcome variable "participating in AMR continuous educational material" This was indicated as the following statement in the questionnaire "You train yourself with continual education material in antimicrobial resistance (AMR) to expand your knowledge, in order to implement good practices of antimicrobial use" with only the following selected variable "veterinary vocational sector": private, public and academic. For 98 responses, notably the outcome variable score was assigned to the following categories "rarely to sometimes" and "frequently to always", the threshold for statistical significance was $p \leq 0.05$, by using the Equation 
1 (Statistics how to, 2021) to compute the results. Furthermore, Minitab ${ }^{\circledR}$ Software 2021 has been used for further analysis.

\section{Equation 1: Pearson's Chi-square}

$$
\chi^{2}=\sum \frac{(O i-E i)^{2}}{E i}
$$

The registered veterinary pharmaceutical drugs from 2017-2020 were directly requested from the JVA, then manually counted according to the registration number. Then, categorized into antibiotic (per oral; parenteral and intramammary only (topical route of administration was not included), antiparasitic and alternatives to antibiotics. Data were entered and quantitatively analysed using Microsoft ${ }^{\circledR}$ Office Excel 2010. reports are not available online; they were requested from JVA via email (JVC,2017;JVC 2018; JVC, 2019; JVC, 2019; JVC 2020).

\section{Results}

\section{KAP survey results}

\section{Demographic Information}

The reported demographic information of the participant (Table 1) showed that most of the veterinarians were residing in Jordan during disturbing the survey period $(87.83 \%$, $101 / 115)$ and around $72 \%(83 / 115)$ are holding an undergraduate academic degree in veterinary medicine and surgery, and the remaining are postgraduate doctors. Most of the participant veterinarians are employed in the private sector $(56.52 \%, 65 / 115)$ and only 6.09 $\%(7 / 115)$ are unemployed. As for the years of experience, half of the participants have gained from one to 5 years of experience in the field $(50.43 \% 58 / 115)$, whereas only $4.348 \%$ (5/115). have experience of more than 30 years.

Table 1: The demographic information of the participants. Source: Authors

\begin{tabular}{|c|c|c|c|}
\hline Variable & Response & $\begin{array}{c}\text { Freq. } \\
(\mathrm{n}=115)\end{array}$ & $\begin{array}{l}\text { Pct. } \\
(\%)\end{array}$ \\
\hline \multirow{2}{*}{$\begin{array}{l}\text { Resident in } \\
\text { Jordan }\end{array}$} & Yes & 101 & $87.83 \%$ \\
\hline & No & 14 & $12.17 \%$ \\
\hline \multirow{3}{*}{$\begin{array}{l}\text { Education } \\
\text { level }\end{array}$} & Bachelor & 83 & $72.17 \%$ \\
\hline & Masters & 24 & $20.87 \%$ \\
\hline & $\mathrm{PhD}$ & 8 & $6.96 \%$ \\
\hline \multirow{7}{*}{$\begin{array}{l}\text { Vocational } \\
\text { sector }\end{array}$} & Private sector & 65 & $56.52 \%$ \\
\hline & Public Sector & 21 & $18.26 \%$ \\
\hline & Academic & 12 & $10.43 \%$ \\
\hline & Other & 1 & $0.87 \%$ \\
\hline & Unemployed & 7 & $6.09 \%$ \\
\hline & Multiple sectors & 7 & $6.09 \%$ \\
\hline & Prefer Not to answer & 2 & $1.74 \%$ \\
\hline \multirow{7}{*}{$\begin{array}{l}\text { Years of } \\
\text { experience }\end{array}$} & $1-5$ & 58 & $50.43 \%$ \\
\hline & $6-10$ & 0 & $0.00 \%$ \\
\hline & $11-15$ & 28 & $24.35 \%$ \\
\hline & $16-20$ & 14 & $12.17 \%$ \\
\hline & $21-25$ & 9 & $7.83 \%$ \\
\hline & $>30$ & 5 & $4.348 \%$ \\
\hline & Prefer not to answer & 1 & $0.870 \%$ \\
\hline \multirow[t]{7}{*}{ Specialty } & Avian & 16 & $13.91 \%$ \\
\hline & Equine & 4 & $3.48 \%$ \\
\hline & Feline and Canine & 22 & $19.13 \%$ \\
\hline & Food animal practice & 24 & $20.87 \%$ \\
\hline & $\begin{array}{l}\text { Mix practices } \\
\text { (wild Animal included) }\end{array}$ & 33 & $28.69 \%$ \\
\hline & Other & 13 & $11.00 \%$ \\
\hline & Prefer not to answer & 3 & $2.609 \%$ \\
\hline
\end{tabular}

Note: Freq.=frequency, Pct $=$ percentage

Around 29\% of the participants have been reported that they practice in more than one animal species avian; equine; feline and canine; food animal and wild animals (28.69\%,33/115), whereas the food animal and feline and canine practice were prominently reported, $20.87 \%$ (24/115) and $19.13 \%$ (22/115), respectively. 


\section{Knowledge}

The knowledge of the participant regarding the AMR was assessed by 6 statements related to the definition of antimicrobial and anti-

microbial resistance and the role of veterinarians in using them, all the statements were correct (Table 2).

Table 2: Knowledge of veterinarians regarding anti-biotic use and resistance. Source: Authors

\begin{tabular}{|c|c|c|c|c|c|c|}
\hline Question & $\begin{array}{c}\text { Agree } \\
\text { Freq. }{ }^{1} \\
(n=115)\end{array}$ & $\operatorname{Pct} \%{ }^{2}$ & $\begin{array}{r}\text { Neutral } \\
\text { Freq. }^{1} \\
(n=115)\end{array}$ & Pct $\%{ }^{2}$ & $\begin{array}{r}\text { Disagree } \\
\text { Freq. } \cdot(n=115)\end{array}$ & Pct $\%{ }^{2}$ \\
\hline $\begin{array}{l}\text { Antimicrobial resistance (AMR) is when a microbe } \\
\text { evolves to become more resistant to antimicrobial } \\
\text { which previously could treat it. Antimicrobials } \\
\text { include antibiotics, which kill or inhibit the growth } \\
\text { of bacteria. }\end{array}$ & 113 & $98.26 \%$ & 1 & $0.87 \%$ & 1 & $0.87 \%$ \\
\hline $\begin{array}{l}\text { Use of veterinary medicinal products, including } \\
\text { antimicrobial agents, is essential for protecting } \\
\text { animal health and welfare, and contributes to food } \\
\text { safety and public health. }\end{array}$ & 91 & $79.13 \%$ & 16 & 13.91 & 8 & $6.96 \%$ \\
\hline $\begin{array}{l}\text { Microorganisms represent a pool of antimicrobial } \\
\text { resistance (AMR) traits in all ecological niches. }\end{array}$ & 79 & $68.70 \%$ & 16 & $13.61 \%$ & 20 & $17.39 \%$ \\
\hline $\begin{array}{l}\text { The excessive use of antimicrobial in livestock (and } \\
\text { aquaculture) will pose a threat to people's } \\
\text { livelihoods. }\end{array}$ & 111 & $96.52 \%$ & 3 & $2.61 \%$ & 1 & $0.87 \%$ \\
\hline $\begin{array}{l}\text { The increased contact between animals and human } \\
\text { beings lead to a higher risk of infections and the } \\
\text { cross-transmission of AMR traits. }\end{array}$ & 87 & $75.65 \%$ & 6 & $5.22 \%$ & 22 & $19.31 \%$ \\
\hline
\end{tabular}

Note: The citations of the mentioned statements are included in Appendix B. Freq. $=$ frequency, Pct $=$ percentage

Most of the participants agreed that the definition of AMR is when a microbe evolves to become more resistant to antimicrobial which previously could treat it $(98.26 \%)$, and $96.52 \%$ agreed that overusing of antimicrobial in livestock will pose a threat to people. Only $79.13 \%$ agreed that the antimicrobial contributes to food safety and public health, and $75.65 \%$ agreed that contact between a human and animals will lead to cross-transmission of AMR. As for the position of AMR in its ecosystem, $17.39 \%$ disagreed that micro- organisms represent a pool of antimicrobial resistance. The average of the participant who had agreed with the statement was $84 \%$, and $7.03 \%$ for the neutral responses, and $9.04 \%$ who had disagreed.

\section{Attitudes}

To evaluate the attitudes of the participants, they were asked questions related to the challenges that they face while tackling AMR. The survey reported that $95.65 \%$ of the participants consider AMR as a challenge for 
the veterinary sector in Jordan and should be prioritized beside other zoonotic diseases such as brucellosis and rabies by the health authorities. Eventually, 53\% of the participants reported that vaccine and vaccination are important for controlling microbial infection in Jordan followed by implementing biosecurity measures, controlling feed and water contamination, and administering probiotics, $42 \%, 13 \%$, and $4 \%$ respectively.

To evaluate the attitudes of the participants, they were asked questions related to the challenges that they face while tackling AMR (Figure 1). The participants believe that the most contributing challenges in evolving the AMR issue in Jordan are the misuse and overuse of antimicrobial by quacks, fraudulent and unauthorized practitioners, such as agricultural engineers, with $68.70 \%$, then the socioeconomic status of customers $(39.13 \%)$. The Jordanian society's view toward the veterinarians, which influence their role in addressing the problem of antimicrobial resistance, and the lack of satisfactory knowledge, competence, and practices of the veterinarian in the field for using alternative, instead of antimicrobials, were the least contributing factors in tackling AMR, with $34.78 \%$ and $33.04 \%$, respectively.

\section{Practices}

To assess the practices of the participant toward AMR, 9 statements concerning their prescription to antimicrobial and their recommendation to the customers (farmers and animal owners, etc....) are presented in (Table 3).
Figure 1: The challenges that face the participants while tackling AMR. Source: Authors*

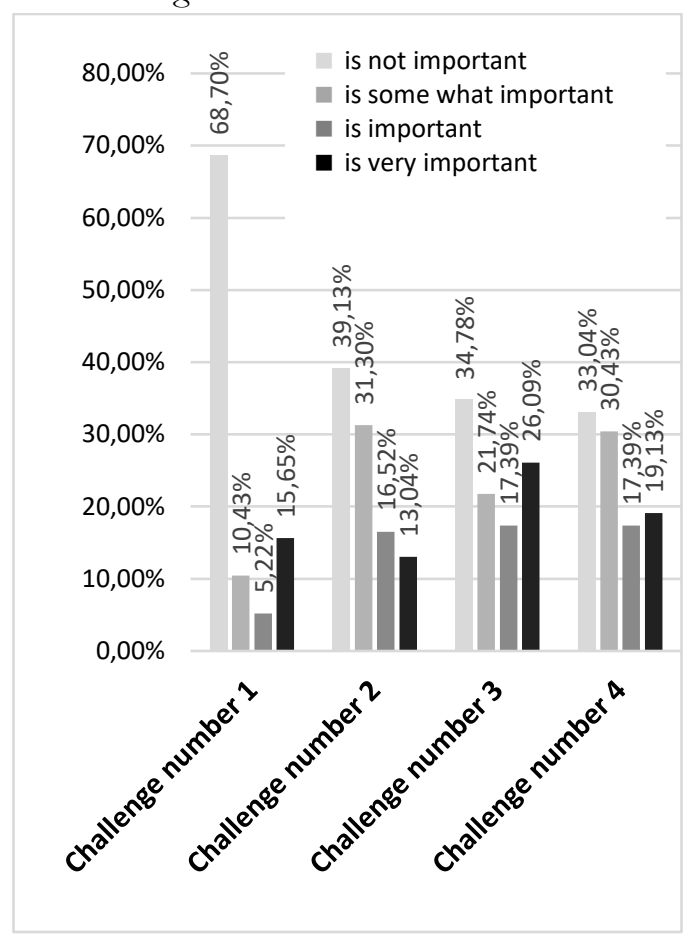

Note. This bar chart shows the importance of each challenge. Challenge number 1 is the misuse and overuse of antimicrobial by quacks, fraudulent and unauthorized veterinarians are contributing to the evolving AMR issue in Jordan; challenge number 2 is the socioeconomic status of customers (farmers, owners..) in Jordan, challenge number 3 is Jordanian society's view of veterinarians has influenced their role in addressing the problem of antibiotic resistance and challenge number 4 is the lack of satisfactory knowledge, competence, and practices of the Jordanian veterinarian in the field of using alternative, instead of antimicrobials.

* The statements of the challenges were formed with assistance of two veterinarians Rana Alshamali and Amjad Awawded.

The survey showed that the most common practice done by the participants was recommending the customers (farmers, owner, etc..) to practice good animal husbandries $(80.00 \%)$, then administering to the patient the correct dose of an antimicrobial with taking into con- 
Table 3: Practices of veterinarians regarding anti-biotic use and resistance. Source: Authors.

\begin{tabular}{|c|c|c|c|c|c|}
\hline Question & Never & Rarely & S.t ${ }^{*}$ & Freq.** & Always \\
\hline $\begin{array}{l}\text { You prescribe antimicrobial drugs only when they are needed to treat } \\
\text { an animal medical condition after a clinical examination, i.e., for } \\
\text { therapeutic purposes. }\end{array}$ & $2.61 \%$ & $0.87 \%$ & $8.70 \%$ & $24.35 \%$ & $63.48 \%$ \\
\hline $\begin{array}{l}\text { You recommend the customers (farmers, owner.) to practice good } \\
\text { animal husbandries such as biosecurity and hygiene. }\end{array}$ & $4.35 \%$ & $0.87 \%$ & $5.22 \%$ & $9.57 \%$ & $80.00 \%$ \\
\hline $\begin{array}{l}\text { You make sure that the specific antimicrobial product you use is the } \\
\text { most appropriate one for that purpose, with taking into consideration } \\
\text { the World Organization for Animal Health OIE list of antimicrobials }\end{array}$ & $6.09 \%$ & $5.22 \%$ & $10.43 \%$ & $21.74 \%$ & $56.52 \%$ \\
\hline $\begin{array}{l}\text { You administer to the patient the correct dose with the correct } \\
\text { frequency and duration, by an appropriate route and treatment protocol } \\
\text { considering the withdrawal period. }\end{array}$ & $4.35 \%$ & $0.00 \%$ & $7.83 \%$ & $21.74 \%$ & $66.09 \%$ \\
\hline $\begin{array}{l}\text { You explain to the customer's (farmers, owners...) that antimicrobial } \\
\text { are not our first choice, and the alternatives to veterinary antimicrobial } \\
\text { are also effective. }\end{array}$ & $4.35 \%$ & $1.74 \%$ & $22.61 \%$ & $20.87 \%$ & $50.43 \%$ \\
\hline $\begin{array}{l}\text { You recommend the customer (farmers, owners...) to wash their hands } \\
\text { frequently after dealing with animals. }\end{array}$ & $6.96 \%$ & $3.48 \%$ & $15.65 \%$ & $14.78 \%$ & $59.13 \%$ \\
\hline $\begin{array}{l}\text { You committed to empowering the customers (farmers, owners...) to } \\
\text { reduce reliance on antimicrobial with at least equal, or improved, animal } \\
\text { health, welfare, and profitability. }\end{array}$ & $3.48 \%$ & $2.61 \%$ & $16.52 \%$ & $20.87 \%$ & $56.52 \%$ \\
\hline $\begin{array}{l}\text { You train yourself with continual education material in antimicrobial } \\
\text { resistance (AMR) to expand your knowledge, to implement good } \\
\text { practices of antimicrobial use }\end{array}$ & $36.52 \%$ & $6.96 \%$ & $10 . .43 \%$ & $13.91 \%$ & $32.17 \%$ \\
\hline $\begin{array}{l}\text { Your level of satisfaction from the veterinary and animal health } \\
\text { services, which are provided by private and public sectors and } \\
\text { associations, in tackling the antimicrobial resistance (AMR) issue in } \\
\text { Jordan. }\end{array}$ & $38.26 \%$ & $19.13 \%$ & $28.70 \%$ & $10.43 \%$ & $3.48 \%$ \\
\hline
\end{tabular}

Note. The citations of the mentioned statements are included in Appendix B.

$*$ S.t. $=$ sometimes $\quad * *$ Freq. $=$ frequently.

sideration the withdrawal period (66.09\%) and prescribing antimicrobial for therapeutic purposes $(63.48 \%)$. More than half $(60 \%)$ of the participant showed that they always do recommending the customer to wash their hands frequently after dealing with animals $(59.13 \%)$, empowering the customers to reduce reliance on antimicrobial. This is besides prescribing the antimicrobial regarding the OIE list of antimicrobial $(56.52 \%)$, and explaining to the customers that the alternatives to veterinary antimicrobial are also effective and the antimicrobial is not the first choice for treatment $(50.43 \%)$.
Only $36.52 \%$ of the participant are not committed to training themselves with continual education material in AMR to expand their knowledge, to implement good practices of antimicrobial use. while $32.17 \%$ are committed to doing that. Low percentage of the participant showed that they are satisfied with the veterinary and animal health services, which are provided by private and public sectors and associations, in tackling the AMR issue in Jordan (3.48\%), while 38.26\% are not satisfied at all. The average of the participant who never did any practice regarding the antibiotic use and resistance was $11.88 \%$, while rarely $4.45 \%$; sometimes $14.01 \%$; frequently $17.58 \%$ and always $51.98 \%$. 
The relationship between participating in AMR continuous education and the parti-cipants vocational sector (private, public and academical sector)

The assessed results of Chi-square test of independence for participating in AMR continuous education (assigned to the category "rarely to sometimes" and "frequently to always") indicated a significant difference across the 98 responses level and the participant vocational sector variable (private, public and academic): $X^{2}=8.34, d f=2, N=$ $98, p=.015$.

The percentage of the registered and re-registered veterinary pharmaceutical drugs between, 2017-2020

The analyzed data of the reports have been categorized according to their pharmaceutical drug's active substance class/per year as Table 4. From this table, it is apparent that the percentage of the registered oral antibiotics during this period was higher for the produced, as the peak of production was in 2018 (32.67\%), as well as the highest percentage for both registered imported and produced oral antibiotic was in 2018 (43.3\%), Figure 3.
In contrast to that, the percentage of the registered parenteral antibiotics was higher for the registered imported pharmaceutical drugs within the range of $8.66 \% \%$ and $25.27 \%$. while the produced was ranged between $2.20 \% \%$ and $15.57 \%$. As for the intramammary antibiotics, the percentage of the produced ranged between $0.00 \%$ and $1.33 \%$, and the percentage of the imported ranged between $0.00 \%$ and $0.91 \%$.

Concerning the antiparasitic drugs, Table 4 demonstrated that the most frequently registered imported veterinary drugs was in 2018, with average of $27.4 \%$ (Figure 2), as well as the highest percentage of both registered imported and produced pharmaceutical drugs was (42.7\%) in 2018 (Figure 3). Besides that, the average percentage of the registered produced is $32.3 \%$ (Figure 2).

The lowest average of the registered veterinary drugs goes to the alternatives of antibiotics (photobiotic) for both produced and imported were $1.1 \%$ and $0.4 \%$, respectively, as it illustrated in Figure 2.

Table 4: The percentage of the registered veterinary pharmaceutical products between 2017 and 2020. Source: Authors

\begin{tabular}{lrrrrrrrr}
\hline \multirow{2}{*}{$\begin{array}{l}\text { Pharmaceutical Drug's } \\
\text { Active Substance Class }\end{array}$} & \multicolumn{3}{c}{$\begin{array}{c}\text { Produced } \\
\text { (percentage per year) }\end{array}$} & \multicolumn{4}{c}{$\begin{array}{c}\text { Imported } \\
\text { (percentage per year) }\end{array}$} \\
\cline { 2 - 10 } & $\mathbf{2 0 1 7}$ & $\mathbf{2 0 1 8}$ & $\mathbf{2 0 1 9}$ & $\mathbf{2 0 2 0}$ & $\mathbf{2 0 1 7}$ & $\mathbf{2 0 1 8}$ & $\mathbf{2 0 1 9}$ & $\mathbf{2 0 2 0}$ \\
\hline Antibiotic (Per Oral) & $19.09 \%$ & $32.67 \%$ & $23.35 \%$ & $15.38 \%$ & $16.36 \%$ & $10.66 \%$ & $16.16 \%$ & $16.48 \%$ \\
Antibiotic (Parenteral) & $4.55 \%$ & $2.67 \%$ & $15.57 \%$ & $2.20 \%$ & $26.36 \%$ & $8.66 \%$ & $17.96 \%$ & $25.27 \%$ \\
Antibiotic (Intramammary) & $0.00 \%$ & $0.67 \%$ & $1.20 \%$ & $0.00 \%$ & $2.73 \%$ & $0.66 \%$ & $0.00 \%$ & $0.00 \%$ \\
Antiparasitic & $16.36 \%$ & $27.33 \%$ & $15.57 \%$ & $26.37 \%$ & $13.64 \%$ & $15.33 \%$ & $9.58 \%$ & $14.28 \%$ \\
Alternatives to antibiotics & $0.00 \%$ & $1.33 \%$ & $0.60 \%$ & $0.00 \%$ & $0.91 \%$ & $0.00 \%$ & $0.00 \%$ & $0.00 \%$ \\
\hline Nitive
\end{tabular}

Note: the original data were adapted from the registered veterinary products reports for each year, with the permission of JVA. 
Figure 2: The average percentage of the registered imported and the produced antimicrobial pharmaceutical drugs between 2017-2020 in Jordan. Source: Authors

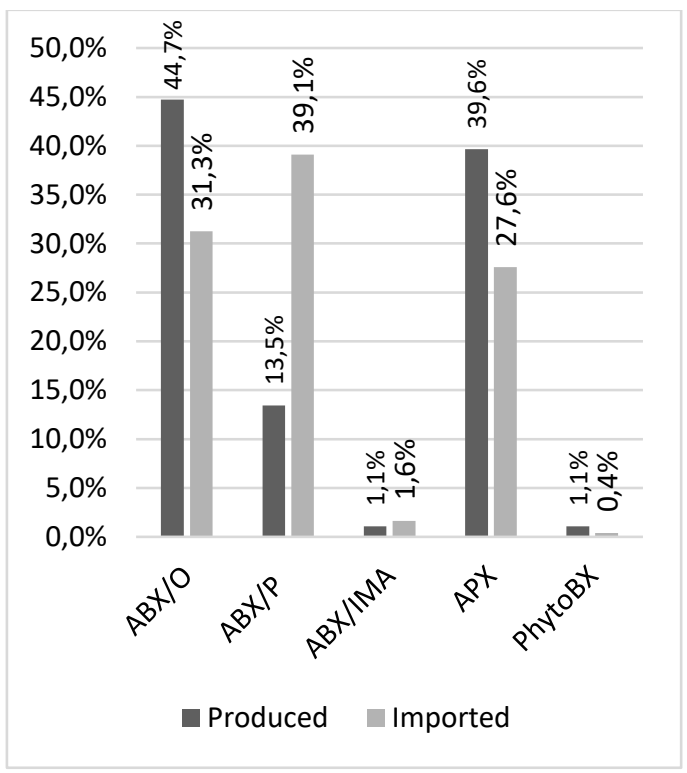

\section{Discussion}

Antimicrobial resistance is a global threat to human and animal health (Aenishaenslin et al., 2019). In Jordan, most of the veterinary studies were conducted on antimicrobial resistance patterns of the pathogens and the risk factors associated with the emergence of the AMR. As for the knowledge, practices, and attitudes, the studies were limited to the medical health sector toward AMR (Ghadeer A. and R. Y. Suaifan, 2012 ;Darwish et al., 2021) and the livestock owners toward Brucella (Musallam et al., 2015). This study focused only on the knowledge, attitudes, and
Figure 3: The percentage of the registered antimicrobial according to their chemical class for each year (2017-2020). Source: Authors

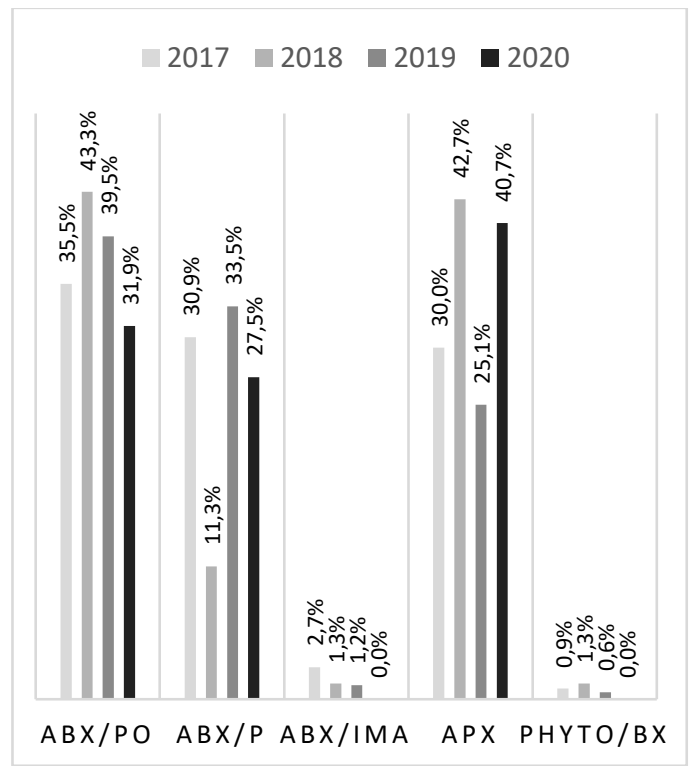

Note: $\mathrm{ABX} / \mathrm{O}=$ oral antibiotic; $\mathrm{ABX} / \mathbf{P}=$ parenteral antibiotic; ABX/IMA = intramammary antibiotics; APX $=$ antiparasitic PHYTOBX $=$ phytobiotics

practices (KAP) of the Jordanian veterinarian toward AMR. In addition to that, this study will outline the registration protocol of the veterinary pharmaceutical products and the data of the registered veterinary pharmaceutical products between 2017-2020.

Regarding antimicrobial resistance knowledge, this study demonstrated that the participants have a very good level of knowledge $(84 \%)$, similar to the level of the Jordanian pharmacists (Darwish et al., 2021), but for example higher than the $69 \%$ of veterinarians in India (Vijay et al., 2021). Most of the participants have agreed with the correct definition of antimicrobial resistance and that 
antimicrobial drugs includes mainly antibiotics. More than $75 \%$ of the participants agreed that the excessive use of antimicrobial in livestock will pose a threat to people's livelihoods and it contributes to food safety and public health, as well as it is essential for protecting animal health and welfare. This latest finding is similar to a Dutch study (Speksnijder et al, 2014), in which the respondents considered that their duty as a veterinarian to treat diseased animals lies on reasons of animal welfare and animal health, regardless of antimicrobial resistance issues. So as and in similar line with the previous study conducted in India that $98.7 \%$ veterinarians believed that antibiotic resistance is a serious public health issue (Vijay et al., 2021). However, $19.36 \%$ of the participants disagreed that the increased contact between animals and human beings could leads to a higher risk of infections and the crosstransmission of AMR traits, and $17.39 \%$ disagreed that microorganisms represent a pool of AMR traits in all ecological niches. Thus, these results demonstrate that the basic knowledge of the participants is satisfactory regarding the AMR definition and it is associated risk, but it needs more improvement in the ecological terms, as it is one of the key elements of the one health approach (McEwen and Collignon, 2018). This is in particular with the high prevalence of the resistant Escherichia coli in the drinking water from Jordan (Swedan and Abu Alrub, 2019). This comes in line with taking into consideration that environmental resistome of the antimicrobial resistance genomes, are now widely recognized as a complex and diversified reservoir of resistance genes that can be transferred into and between environmental and clinically relevant bacteria (EMA and CVMP, 2018). which means that the environmental aspect is being critical. Therefore, they should have sufficient acquaintances regarding that water bodies polluted with resistant genes, bacteria and antimicrobial compounds from human and animal faeces and antimicrobial manufacturing are also an ideal environment for emerge and spread of superbugs (WHO, 2020).

This study revealed that most of the participants consider AMR as a challenge and should be prioritized. A $68.70 \%$ believes that the most contributing challenge is the misuse and overuse of antimicrobial participant by unqualified professions to prescribe veterinary medication. A recent study in India showed that their prescription practices could jeopardize on-going AMR-mitigation efforts (Mutua et al., 2020). For instance, the Indian dairy farmer chooses to deal with quacks instead of veterinarians due to high cost of animal treatment (Vijay et al., 2021). In Jordan, the legislation grants permission for non-veterinarian (Agricultural Engineers) to provide antimicrobial products without veterinary supervision, even though, do not have sufficient training nor do have the required background to dispense antimicrobials unsupervised by a veterinarian (WHO,2018).The high cost of animal treatment correlated with the socioeconomic status of the customers as this study showed that around 39\% believe in that. This finding comes in parallel with similar study done by the Jordanian pharmacist that showed the socioeconomic status of the patients reflects their health literacy level 
(Darwish et al., 2021). Consequently, the legislation should be modified to embrace the role of the veterinarian alongside other health professions in the AMR stewardship besides the other detected zoonotic diseases in the country: brucellosis, and rabies (Sorrell et al., 2015).

Veterinarians have an influential responsibility regarding the hygienic practices and thus reducing AMR. This study reported that $42 \%$ of the respondents considered that implementing biosecurity measures is critical to control microbial infection, likewise, $80 \%$ of them are consistently recommending the customers (client, owner, farmer...) for good hygiene practices and 59.13\% recommend them to wash their hands after dealing with animals.

Considerable animal health studies were conducted in Jordan, has shown that the hygienic practices are associated with emerging antimicrobial-resistant drugs. The risk factor associated with the emergence of Avian Pathogenic Escherichia coli (APEC) was correlated with inadequate hygienic practices, as well as it also correlated with the inappropriate use of antimicrobials along with the highest resistance was found against sulfamethoxazole-trimethoprim, florfenicol, amoxicillin, doxycycline and spectinomycin (Ibrahim et al., 2019). This also comes in corresponding with the high prevalence and distribution of antimicrobial resistance genes (ARGs) of Escherichia coli isolates obtained from equine faecal samples (Gharaibeh et al., 2020). The high prevalence of antimicrobial resistance of mecA and mecC methicillinresistant Staphylococcus aureus (MRSA) in cattle, sheep, and goat dairy farms in Jordan, needs a strict hygiene measure, as it leads to an economic loss in the dairy industry (Obaidat et al., 2017). Furthermore, the antibiotic resistance of isolated Campylobacter jejuni and Campylobacter coli from chickens in Jordan, is due to a lack of hygienic measures at slaughterhouses and the unregulated use of antibiotics has led to high levels of resistance in Jordan (Alaboudi et al., 2020). Thus, the responsibility of recommending hygienic practices in animal health besides regulating the use of antibiotics is associated with reducing antibiotic resistance rests partly on veterinarians.

Regarding their practices while determining antimicrobials, $63.48 \%$ respondents always prescribe antimicrobial for therapeutical practice; $66.06 \%$ of them indicated that they take into consideration the withdrawal period and administering them with the correct dose and frequency. Also $56.52 \%$ of them take in consideration the OIE list of antimicrobials while choosing them, as well as they encourage the customers to reduce their reliance on them, and 50.43\% recommend the customers to use alternatives to antimicrobials. Previous studies in India showed that the uses of alternative therapies such as herbal medicines were reported by $74.0 \%$ of veterinarians and are widely used in bovine therapeutics (Sharma et al., 2020). These latest observations suggest, around half of the respondents may need further improvement in their advisory skills and involving them with regular training regarding the updated treatment guideline, to put knowledge into practice, as the correct selection and administration of antimicrobials are important to structure the future intervention in re- 
ducing antimicrobial resistance (Speksnijder et al., 2014). Hence around a third of the participants $(36.52 \%)$ have never been committed to training themselves with continual education material in antimicrobial resistance (AMR), due to lack of unpaid or affordable training and their economic status. This study also demonstrates the that there is a relationship between the participant willing to enrol themselves in AMR continual educational material and their vocational sector's. This finding suggests to implement an AMR continual educational / training program that involves the best practices toward AMR during academic as it is done in Nigeria (Adekanye et al., 2020). Thus it will give the opportunity to all veterinarians, before graduations and being employed in different sectors, to expand and update their knowledge regarding AMR and antimicrobial stewardship (Adekanye et al., 2020). On similar line and at the end of 2020, JUST held a workshop entitled: Raising awareness about the judicious use of antibiotics in the livestock sector in Jordan that discussed the role of veterinarians in reducing the excessive use of veterinary medicines, for the veterinarians and farmer (Rababah, 2020).

Moreover, $38.26 \%$ of respondent were not satisfied at all from the animal health services, whether from private or public sector or even the association in addressing the AMR issue. This means that the limited and the low frequency of the provided animal health service is an obstacle to tackle AMR. Furthermore, there was neither professional training of veterinary related professionals (veterinarians and veterinary paraprofessionals) nor for key stakeholders (farmers and farm workers, extension workers, food and feed processors and retailers) or environmental specialists, related to AMR, as well as no systematic approach at national level to strengthening Veterinary Services (TrACSS, 2018). This means that the framework of the AMR policy will be held by human health stakeholder, and "in the since of guilty" the veterinarian will be part of it, as the sales of veterinary drugs is source of their income (Fortané, 2019). At the same time, reinforcing the veterinarians and the stakeholder's role is important in improving the animal health as the intensive contact between the farmers and the veterinarians will improve the animal health issue (Speksnijder et al., 2014).

Transboundary problems related to animal diseases, residues of veterinary drugs in food products, and resistance to antibiotics created a demand for regulations that are satisfied by the national regulations (Sager et al, 2021). This comes with parallel with the observations that the main cause of residues is the failure to meet the withdrawal period; improper use of licensed pharmaceutical drugs and the illegal use of unlicensed pharmaceutical drugs (Alaboudi, n.d.).

The residue of antibiotics stimulates microbial resistance after sub-therapeutic doses and it's risk will increase AMR transferred into food borne pathogens, such as Erythromycin Resistant Campylobacter spp.. and Vancomycin Resistant Enterococci spp.. The pathogenic bacteria can pick up the AMR genes from the gene pool, which they are presented in food either as DNA fragments or enclosed in bacteria and bacteriophages, and then transfer them to another pathogenic 
bacteria (Alaboudi, n.d, and Osaili and Alboudi, 2017).

In Jordan, the animal health sector is well served by the Agriculture Law No. 13 of 2015, in which the instructions for registering the antimicrobial drugs are included and that responsibility falls under the Pharmaceutical products registration and monitoring division at MOA, i.e. Veterinary Services Department (WHO, 2018). To register the veterinary pharmaceutical drug, the Veterinary Services Directorate depends on the guidelines of the International Cooperation on Harmonization of Technical Requirements for Registration of Veterinary Medicinal Products (VICH) (FAO, 2015), and OIE (Alfawarah, 2021). Two of the VICH guidelines are related to the antimicrobial resistance, the first one VICH GL 27, which outlines the types of studies and data that are recommended for characterizing the potential resistance development that might occur in the food-producing animal under the proposed conditions of use of the product. Whereas the second one is VICH GL 36, which guidance for assessing the human food safety of residues from veterinary antimicrobial drugs. This being concerns with effects on the human intestinal flora because if a drug is intended for use in food-producing animals has antimicrobial activity, the safety of its residues needs to be addressed concerning the human intestinal flora (Sander et al., 2010).

The antimicrobial registration process undergoes continuous modernization in Jordan (WHO, 2018), for instance the veterinary committee will not accept the registration of the pharmaceutical drug, unless the Good Manufacturing Practice (GMP) of the manufacturing company is authorized from the country of origin or the request will be rejected (FAO, 2015). In addition to that, the Certificate of Pharmaceutical Product (CPP), which is in the recommended format by WHO, and the authorized Certificate of Free Sale (CFS), which is a vital certificate to ensure that the veterinary pharmaceutical products are marketed in the country of origin and are eligible for export. It also involve prevalence of the technical data package of the pharmaceutical product, which include the following: specifications; stability data; impurity data; method of analysis and it's validation's and schematic synthetic route (FAO, 2015). Despite that, the veterinary pharmaceutical products registration division has no reliable data on antimicrobial use, quantity imported or manufactured in the country, and has no control over regulating antimicrobial product importation to maintain a safe pool in-country (WHO, 2018).

The approval for the use of the veterinary pharmaceutical drugs is one of the main contributor in increasing the resistance among human isolates to most of antibiotics as the general level of the resistance among the animal or human isolates depends on the regulation concerning the control on using the animal and human pharmaceutical drugs wisely (Osaili and Alaboudi,2017). The Food Safety Commission of Japan introduced the ranking of antimicrobials according to their importance for the treatment of human infections with antimicrobial-resistant bacteria through food commodities, and it is the basic material to be used in risk assessment of foodborne antimicrobial-resistant bacteria (CVMP, 2019). Based on that, the developed ranking is the following: Critically and highly 
important and important. Regarding the critically important, which could be the only pharmaceutical drug to be prescribed or hardly to find any alternatives to treat a certain human disease, for instance the 3rd and 4th generation of cephalosporins.

The findings in the reports of registered pharmaceutical products between 2017 and 2020 described them as only registered for the parenteral route of administration, which is similar to the French reports (ANSES, 2020), because they are poorly absorbed after oral administration (Hornish and Katarski, 2002) and the spread of AMR in the fecal flora will impact the environment (EMA and CVMP, 2018). In Jordan Salmonella enterica isolates from imported meat carcass resisted several treatment-of-choice antimicrobials such as ciprofloxacin (26.8\%) and ceftriaxone (19.5 $\%$ ) (Obaidat, 2020). The application of ceftiofur requires a veterinarian-client-patient relationship (VCPR), which represents the legal and ethical requirement that the veterinarian assume responsibility for determining the need for medical treatment of animals based on direct knowledge of their health and management. It is distinctively labeled for control (therapeutic) not prevention (prophylactic), as the mass application may lead to the emergence and dissemination of extended-spectrum cephalosporin-resistant Salmonella and of resistance genes such as bla CTX-M (Wittum, 2012). Furthermore, the third and the fourth generation of cephalosporin and colistin are classified within the reserved group, which means they should be treated with the last resort option (WHO, 2019). Even though, colistin is registered for oral administration, and used as a growth promoter for food animals, it may contributes to emerging of mcr-1 gene in colistin resistant bacterial isolates (Vidovic and Vidovic, 2020). Moreover, it has been reported that enrofloxacin, a fluoroquinolone drug, has been registered for oral administration such as in France (ANSES, 2020). However, it is banned for mass medication in some countries such as the USA, as it leads to the emergence and zoonotic food-borne transmission of fluoroquinolone-resistant Campylobacter jejuni in the early 2000s (Wittum, 2012). However, a study was conducted on the local table egg in Jordan revealed the prevalence rate of enrofloxacin in the as the lowest $(0.8 \%)$ among the detected four antimicrobial, whereas the sulfonamide was at the highest rank (5.2\%) (Alaboudi et. Al,2013) .

Ionophores, such as monensin; maduramycin; salinomycin, appeared to be registered, as it fed to the livestock as a growth promotor, even that the recent regulations are making efforts to ban prescribing antibiotics as growth promoters (WHO, 2018). However due to the complexity and high degree of specificity of ionophore resistance, it appears that ionophores do not contribute to the development of antibiotic resistance to important human drugs and will continue to play a significant role in improving the efficiency of animal production in the future (Callaway T. et al., 2003).

Regarding the Intramammary antibiotic, which is a local treatment and/or prevention for udder infections for ruminants, especially during the lactation period. The produced milk, or the wasted milk, is not marketable for human consumption during the treatment or 
more than one day of the treatment (BIOHAZ et al., 2017).

Regarding the public health perspective of the wasted milk, most of the antimicrobial that is used for intramammary infections are shared with human medicine. The majority of the registered produced and imported drugs are composed of critically important antimicrobial which is shared with human medicine, such as cephalosporins (cefalenium and cefalexin), aminoglycosides (neomycin and gentamycin) and penicillin (cloxacillin and ampicillin), as both the categorized in the high priority critically important antimicrobials (WHO, 2017).

For the registered antiparasitic veterinary pharmaceutical drugs, the route of administration varies between parenteral (e.g. ivermectin IM/SC injections), oral (e.g. albendazole tablets), and topical (e.g. cypermethrin dusting powder). During the period 2017-2020, the quantity of the registered antiparasitic drugs which were prescribed to treat endoparasites is higher than the one that is used to treat the ectoparasites, for both import and export. Although the reports revealed that the registered produced ectoparasitic drugs are around 4 times higher than the imported ones (total of the registered ectoparasites for imported 14 while 44 for the produced), which indicates that the sector depends on the local market.

Lack of clear OIE standards and guidelines on antiparasitic products contributed to the AMR challenge due to many reasons, which have been addressed by the OIE. Firstly, there is a lack of effective drugs and resistance to many antiparasitic, especially to trypanocides, ascarids, and anthelmintic resistance.
Secondly, lack of good quality antiparasitic drugs and poor quality are available as most of the available drugs have been used for more than 50 years and the availability substandard and falsified products. Finally, the presence of antiparasitic residues in the environment especially for ivermectin and toltrazuril (Szabó, 2020).

A study was conducted on the home produced eggs in Jordan revealed that are highly contaminated with pesticide residues particularly Malathion (44\%) and Aldrin (33\%), at an unacceptable high limits and form potential harmful to the consumer (Alaboudi et al., 2019).

Plants extract or phytobiotics has been used widely in veterinary medicine, as their residue is not considered for it is toxicological concerns and due to their antimicrobial, antiinflammatory, anti-oxidative, and anti-parasitic activities. In addition to that, they are considered as alternatives to antimicrobial drugs, and they play a significant role in improving animal performance and control diseases under certain circumstances (Cheng et al., 2014). Most of the registered produced drugs during this period were extracted from menthol and thymol. However that the percentage of the total registered phytobiotocs was around 1\% from the total registered drugs between 2017-2020, while in some African countries the percentage was $0.002 \%$ (1/470) (IGAD MRH, 2021), but at least it is considered a step toward reducing AMR in animals.

\section{Conclusion}

The present study evaluated the existing approach of the role of the Jordanian vete- 
rinarian in tackling AMR toward one health. The KAP survey has highlighted the following:

(1) The demographic information of the respondent and their knowledge, attitudes, and practices toward AMR.

(2) AMR is a challenge for national animal health.

(3) The quacks or the unauthorized practitioners has been addressed as the main contributors to overusing and misusing antimicrobials.

(4) Implementing antimicrobial resistance continual educational program is essential to improve the veterinarian knowledge in all aspects of AMR.

(5) Obligating legislations that ensure the veterinarian to prescribe the correct antimicrobials and improving the surveillance system to monitor the antimicrobial consumption in the veterinary field.

(6) The lack of interest of some of the participants in AMR topics is considered a limitation to the study.

(7) The low response rate is due to low acceptability to social media or internet access.

(8) Besides the KAP survey, this study outlined the regulatory aspect of the authorized registered veterinary pharmaceutical drugs in Jordan.

\section{References}

Adekanye, U., Ekiri, A., Galipó, E., Muhammad, A., Mateus, A., La Ragione, R., Wakawa, A., Armson, B., Mijten, E., Alafiatayo, R., Varga, G. and Cook, A., (2020). Knowledge, Attitudes and Practices of Veterinarians Towards
Antimicrobial Resistance and Stewardship in Nigeria. Antibiotics, [online] 9(8), p.453. Available at:

$<$ https://doi.org/10.3390/antibiotics908 0453> [Accessed 30 April 2021].

Aenishaenslin, C., Häsler, B., Ravel, A., Parmley, J., Stärk, K. and Buckeridge, D., (2019). Evidence needed for antimicrobial resistance surveillance systems. Bulletin of the World Health Organization, [online] 97(4), pp.283-289. Available at: $<$ https://dx.doi.org/10.2471/BLT.18.21 8917> [Accessed 23 April 2021]. Alaboudi, A., (n.d). Drug residues in egg and poultry meat. [Accessed 25 April 2021]. Alaboudi, A., Basha, E. and Musallam, I., (2013). Chlortetracycline and sulfanilamide residues in table eggs: Prevalence, distribution between yolk and white and effect of refrigeration and heat treatment. Food Control, [online] 33(1), pp.281-286. Available at: $<$ https://doi.org/10.1016/j.foodcont.201 3.03.014> [Accessed 26 April 2021].

Alaboudi, A., Malkawi, I., Osaili, T., AbuBasha, E. and Guitian, J., (2020).

Prevalence, antibiotic resistance and genotypes of Campylobacter jejuni and Campylobacter coli isolated from chickens in Irbid governorate, Jordan. International Journal of Food Microbiology, [online] 327, p.108656. Available at:

<https://doi.org/10.1016/j.ijfoodmicro.2 $\underline{020.108656}>$ [Accessed 5 February 2021]. Alaboudi, A., Osaili, T. and Alrwashdeh, A., (2019). Pesticides

(Hexachlorocyclohexane, Aldrin, and Malathion) Residues in Home-Grown Eggs: Prevalence, Distribution, and Effect 
of Storage and Heat Treatments. Journal of Food Science, [online] 84(12), pp.3383-3390. Available at:

$<$ https://doi.org/10.1111/17503841.14918> [Accessed 26 April 2021].

Alfawarah, S., (2021). Jordanian Regulations for registering the veterinary pharmaceutical products.

Alshamali, R. and Awawdeh, A., (2021). The attitudes of the veterinarians in Jordan in tackling AMR. (personal communication)

Amrcountryprogress.org. (2018). Global Database for the Tripartite Antimicrobial Resistance (AMR) Country Self-assessment Survey (TrACSS). [online] Available at: $<$ https://amrcountryprogress.org/> [Accessed 3 March 2021].

Australian Veterinarian Association (AVA), (2021). Use of antimicrobial drugs in veterinary practice. [online] Ava.com.au. Available at: <https://www.ava.com.au/policyadvocacy/policies/use-of-veterinarymedicines/use-of-antimicrobial-drugs-inveterinary-practice/ $>$ [Accessed 8 February 2021].

EFSA Panel on Biological Hazards (BIOHAZ), Ricci, A., Allende, A., Bolton, D., Chemaly, M., Davies, R., Fernández Escámez, P., Girones, R., Koutsoumanis, K., Lindqvist, R., Nørrung, B., Robertson, L., Ru, G., Sanaa, M., Simmons, M., Skandamis, P., Snary, E., Speybroeck, N., Kuile, B., Threlfall, J., Wahlström, H., Bengtsson, B., Bouchard, D., Randall, L., Tenhagen, B., Verdon, E., Wallace, J., Brozzi, R., Guerra, B., Liebana, E., Stella, P. and Herman, L., 2017. Risk for the development of Antimicrobial Resistance (AMR) due to feeding of calves with milk containing residues of antibiotics. EFS $A$ Journal, [online] 15(1). Available at: < https://doi.org/10.2903/j.efsa.2017.466 $\underline{5}>$ [Accessed 4 February 2021]. Callaway TR, Edrington TS, Rychlik JL, Genovese KJ, Poole TL, Jung YS, Bischoff KM, Anderson RC, Nisbet DJ., (2003). Ionophores: their use as ruminant growth promotant's and impact on food safety. Curr Issues Intest Microbiol4,[online](2):43-51. PMID: 14503688.

Cheng, G., Hao, H., Xie, S., Wang, X., Dai, M., Huang, L. and Yuan, Z., (2014). Antibiotic alternatives: the substitution of antibiotics in animal husbandry. Frontiers in Microbiology, [online] 5, p.217. Available at:

$<$ https://dx.doi.org/10.3389\%2Ffmicb.2 014.00217> [Accessed 6 March 2021].

Committee for Medicinal Products for Veterinary Use, (2019). Advice on implementing measures under Article 37(4) of Regulation (EU) 2019/6 on veterinary medicinal products - Criteria for the designation of antimicrobials to be reserved for treatment of certain infections in humans. [online] Amsterdam: European Medicines Agency. Available at: <https://www.ema.europa.eu/en/docum ents/regulatory-proceduralguideline/advice-implementing-measuresunder-article-374-regulation-eu-2019/6veterinary-medicinal-products-criteriadesignation-antimicrobials-be-reservedtreatment-certain_en.pdf $>$ [Accessed 5 March 2021].

Darwish, R., Baqain, G., Aladwan, H., Salamah, L., Madi, R. and Masri, R., 
(2021). Knowledge, attitudes, and practices regarding antibiotic use and resistance among community pharmacists: a cross sectional study in Jordan. International Journal of Clinical Pharmacy, [online] Available at: $<\underline{\text { https://doi.org/10.1007/s11096-021- }}$ 01234-1> [Accessed 15 February 2021].

European Medicine Agency (EMA) and Committee for Medicinal Products for Veterinary Use (CVMP), (2018). Reflection paper on antimicrobial resistance in the 5 environments: considerations for current and future risk 6 assessment of veterinary medicinal products. [online] London: European Medicine Agency (EMA). Available at: <https://www.ema.europa.eu/en/docum ents/scientific-guideline/draft-reflectionpaper-antimicrobial-resistanceenvironment-considerations-currentfuture-risk_en.pdf $>$ [Accessed 12 February 2021].

European Medicine Agency, (2009). Joint Opinion on antimicrobial resistance (AMR) focused on zoonotic infections. Brussel: European Medicine Agency.

European Medicines Agency. Antimicrobial resistance - European Medicines Agency.

[online] Available at: < https://www.ema.europa.eu/en/human -regulatory/overview/public-healththreats/antimicrobial-resistance> [Accessed 19 January 2021].

FAO.Org. Food and Agriculture Organization (FAO). (2015). Agricultural Law No.13 of 2015. [online] Available at: <http://www.fao.org/faolex/results/det ails/en/c/LEX-FAOC149617>

[Accessed 7 February 2021].
Farm Animal Welfare Committee, (2012). Farm Animal Welfare: Health and Disease. [online] London: Farm Animal Welfare Committee. Available at: $<$ https:/ /assets.publishing.service.gov.uk /government/uploads/system/uploads /a ttachment_data/file/324616/FAWC_rep ort_on_farm_animal_welfare__health_and_disease.pdf $>$ [Accessed 19 February 2021].

Food and Agriculture Organization (FAO).(2020). FAOSTAT. [online] Available at: <http://www.fao.org/faostat/en/\#coun try/112> [Accessed 3 January 2021].

Food and Agriculture Organization of the United Nations (FAO). 2016. General profile. [online] Available at: $<$ http://www.fao.org/countryprofiles/in $\mathrm{dex} / \mathrm{en} /$ ?iso3=JOR\#> [Accessed 3 January 2021].

Fortané, N., (2019). Veterinarian 'responsibility': conflicts of definition and appropriation surrounding the public problem of antimicrobial resistance in France. Palgrave Communications, [online] 5(1). Available at:

$<\underline{\text { https://doi.org/10.1057/s41599-019- }}$ 0273-2> [Accessed 4 March 2021].

French Agency for Food, Environmental and Occupational Health \& Safety (ANSES), (2020). Sales Survey of Veterinary Medicinal Products Containing Antimicrobials in France in 2019,. [online] France: ANSES-ANMV, p.97. Available at: <https://www.anses.fr/en/system/files/ ANMV-Ra-Antibiotiques2019EN.pdf> [Accessed 3 March 2021]. 
Geology.com. (2008). Jordan Map and Satellite Image. [online] Available at:

$<$ https://geology.com/world/jordansatellite-image.shtml $>$ [Accessed 3 January 2021].

Ghadeer A. R. Y. Suaifan, (2012). A crosssectional study on knowledge, attitude and behavior related to $\backslash$ antibiotic use and resistance among medical and nonmedical university students in Jordan. African Journal of Pharmacy and Pharmacology, [online] 6(10). Available at: < https://doi.org/10.5897/AJPP12.080 $>$ [Accessed 14 February 2021].

Gharaibeh, M., Abutarbush, S., Mustafa, F., Lafi, S. and Halaiqa, M., (2020). Identification of risk factors associated with antimicrobial resistance in equine fecal Escherichia coli isolates. Infection, Genetics and Evolution, [online] 83, p.104317. Available at: $<$ https://doi.org/10.1016/j.meegid.2020. 104317> [Accessed 3 February 2021].

Hornish, R. and Katarski, S., (2002). Cephalosporins in Veterinary Medicine Ceftiofur Use in Food Animals. Current Topics in Medicinal Chemistry, [online] 2(7), pp.717-731. Available at: $<$ http://dx.doi.org/10.2174/1568026023 393679> [Accessed 8 February 2021].

Rababah I., (2020). Workshop on the judicious use of antibiotics in the livestock sector at Jordan University of Science and Technology. [online] Available at:

<https://www.just.edu.jo/NewsCenter/ Lists/JustNews/DisplayItem.aspx?ID=16 05> [Accessed 12 March 2021].

Ibrahim, R., Cryer, T., Lafi, S., Basha, E., Good, L. and Tarazi, Y., (2019).
Identification of Escherichia coli from broiler chickens in Jordan, their antimicrobial resistance, gene characterization and the associated risk factors. BMC Veterinary Research, [online] 15(1). Available at: < https://doi.org/10.1186/s12917-0191901-1> [Accessed 4 March 2021]. Jordanian Veterinarian Association (JVA). (2013). Jordanian Veterinarian association in brief. [online] Available at:

$<$ http://www.jordanvet.org/line.php?no=1> [Accessed 3 January 2021].

Jordanian Veterinary Committee, ( 2017). Drugs 2017. Amman: Jordanian Veterinary Committee.

Jordanian Veterinary Committee, (2018). Drug 2018. Amman: Jordanian Veterinary Committee.

Jordanian Veterinary Committee, (2019). Registered drugs 2019. Amman: Jordanian Veterinary Committee. Jordanian Veterinary Committee, (2019). ReRegistered drugs 2019. Amman: Jordanian Veterinary Committee.

Jordanian Veterinary Committee, (2020). Report 2020. Amman: Jordanian Veterinary Committee. Just.edu.jo. 2021. Welcome. [online] Available at:

<https://www.just.edu.jo/FacultiesandD epartments/FacultyOfVeterinaryMedicine /Pages/Veterinary\%20Medicine.aspx> [Accessed 3 January 2021].

Lindal, E. and Westergaard, J., (2014). Biosecurity and livestock production. Available at: < http://www.divaportal.org/smash/get/diva2:910028/FUL 
LTEXT01.pdf $>$ [Accessed 19 January 2021].

McEwen, S. and Collignon, P., (2018). Antimicrobial Resistance: a One Health Perspective. Antimicrobial Resistance in Bacteria from Livestock and Companion Animals, [online] 6(2), pp.521-547. Available at:

$<$ https://doi.org/10.1128/microbiolspec. arba-0009-2017> [Accessed 18 February 2021].

McKellar, Q., 1998. Antimicrobial resistance: a veterinary perspective. $B M J$, [online] 317(7159), pp.610-611. Available at:

$<$ https://dx.doi.org/10.1136\%2Fbmj.317

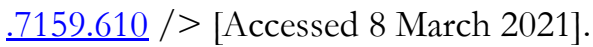

Mrh.igad.int. (202). IGAD MRH | dashboard. [online] Available at:

$<$ https://mrh.igad.int/production/index $>$ [Accessed 6 February 2021].

Musallam, I., Abo-Shehada, M., HEGAZY, Y., HOLT, H. and GUITIAN, F., (2015). Systematic review of brucellosis in the Middle East: disease frequency in ruminants and humans and risk factors for human infection. Epidemiology and Infection, [online] 144(4), pp.671-685. Available at: $<\underline{\text { https://doi.org/10.1017/s09502688150 }}$ $\underline{02575}>$ [Accessed 6 February 2021].

Mutua, F., Sharma, G., Grace, D., Bandyopadhyay, S., Shome, B. and Lindahl, J., (2020). A review of animal health and drug use practices in India, and their possible link to antimicrobial resistance. Antimicrobial Resistance \& Infection Control, [online] 9(1). Available at:
$<$ https://doi.org/10.1186/s13756-02000760-3> [Accessed 8 February 2021].

Obaidat, M., (2020). Prevalence and antimicrobial resistance of Listeria monocytogenes, Salmonella enterica and Escherichia coli O157:H7 in imported beef cattle in Jordan. Comparative Immunology, Microbiology and Infectious Diseases, [online] 70, p.101447. Available at: $<$ https://doi.org/10.1016/i.cimid.2020.1 01447> [Accessed 3 February 2021].

Obaidat, M., Bani Salman, A. and Roess, A., (2017). High prevalence and antimicrobial resistance of mecA Staphylococcus aureus in dairy cattle, sheep, and goat bulk tank milk in Jordan. Tropical Animal Health and Production, [online] 50(2), pp.405-412.

Available at: < https://doi.org/10.1007/s11250-0171449-7> [Accessed 5 February 2021].

Osaili, T. and Alaboudi, A., (2017). Foodborne pathogens and antibiotic resistance. 1st ed. New Jersey: John Wiley \& Sons, Inc. Available at:

< https://doi.org/10.1002/978111913918 8.ch18 $>$ [Accessed 25 April 2021].

Palma, E., Tilocca, B. and Roncada, P., (2020). Antimicrobial Resistance in Veterinary Medicine: An Overview. International Journal of Molecular Sciences, [online] 21(6), p.1914. Available at: $<$

https://dx.doi.org/10.3390\%2Fijms2106 1914> [Accessed 8 March 2021].

Sager, F., Thomann, E., Zollinger, C. and Mavrot, C., (2014). Confronting Theories of European Integration: A Comparative Congruence Analysis of Veterinary Drug Regulations in Five Countries. [online] 15(5): 
457-474.Available at:

< http://dx.doi.org/10.1080/13876988.20

14.960244> [Accessed 7 March 2021].

Sander, P., Anses, French Agency for Food,

Environmental and Occupational Health

Safety, Fougères and Member of

SAGAM, (2010). Overview of CVMP

Activities on antimicrobial resistance.

Sharma, G., Mutua, F., Deka, R., Shome, R.,

Bandyopadhyay, S., Shome, B., Goyal

Kumar, N., Grace, D., Dey, T.,

Venugopal, N., Sahay, S. and Lindahl, J.,

(2020). A qualitative study on antibiotic

use and animal health management in

smallholder dairy farms of four regions of

India. Infection Ecology \& Epidemiology,

[online] 10(1), p.1792033. Available at:

$<$ https://doi.org/10.1080/20008686.202

$\underline{0.1792033}>$ [Accessed 17 April 2021].

Sorrell, E., El Azhari, M., Maswdeh, N.,

Kornblet, S., Standley, C., Katz, R.,

Ablan, I. and Fischer, J., (2015). Mapping of Networks to Detect Priority Zoonoses in Jordan. Frontiers in Public Health, [online] 3(219). Available at:

< https://doi.org/10.3389/fpubh.2015.00

219 > [Accessed 3 February 2021].

Speksnijder, D., Jaarsma, A., van der Gugten,

A., Verheij, T. and Wagenaar, J., (2014).

Determinants Associated with Veterinary

Antimicrobial Prescribing in Farm

Animals in the Netherlands: A Qualitative

Study. Zoonoses and Public Health, [online]

62, pp.39-51. Available at:

< https://doi.org/10.1111/zph.12168>

[Accessed 3 March 2021].

Speksnijder, D., Mevius, D., Bruschke, C.

and Wagenaar, J., (2014). Reduction of

Veterinary Antimicrobial Use in the
Netherlands. The Dutch Success

Model. Zoonoses and Public Health, [online]

62(suppl. 1), pp.79-87. Available at:

< https://doi.org/10.1111/zph.12167>

[Accessed 5 February 2021].

Starr, M. and Reynolds, D., (1951).

Streptomycin Resistance of Coliform

Bacteria from Turkeys Fed

Streptomycin. American Journal of Public

Health and the Nation's Health, [online]

41(11_Pt_1), pp.1375-1380. Available at:

<https://dx.doi.org/10.2105\%2Fajph.41.

11 pt 1.1375/> [Accessed 6 March

2021].

Statisticshowto.com, (2021). What is chi-square statistics? [online] Available at:

<https://www.statisticshowto.com/prob ability-and-statistics/chi-

square/ $>$ [Accessed 30 April 2021].

Stull, J., Brophy, J. and Weese, J., (2015).

Reducing the risk of pet-associated zoonotic infections. Canadian Medical Association Journal, [online] 187(10), pp.736-743. Available at: < https://dx.doi.org/10.1503\%2Fcmaj.141 $\underline{020}>$ [Accessed 8 January 2021].

Swedan, S. and Abu Alrub, H., (2019).

Antimicrobial Resistance, Virulence

Factors, and Pathotypes of Escherichia

coli Isolated from Drinking Water

Sources in Jordan. Pathogens, [online] 8(2),

p.86. Available at:

< https://dx.doi.org/10.3390\%2Fpathoge ns8020086 > [Accessed 8 February 2020].

Szabó, D., (2020) Antiparasitic resistance: update on the planned activities. Available at: $<$ https://rr-asia.oie.int/wpcontent/uploads/2020/01/25a-szabo- 
oie-antiparasitic-resistance.pdf $>$

[Accessed 8 February 2020].

United Nation Population Fund Jordan

(UNFPA). (2021). About Jordan. [online]

Available at:

$<$ https://jordan.unfpa.org/en/about-

jordan $>$ [Accessed 3 January 2021].

Van Boeckel, T., Brower, C., Gilbert, M.,

Grenfell, B., Levin, S., Robinson, T.,

Teillant, A. and Laxminarayan, R., (2015).

Global trends in antimicrobial use in food animals. Proceedings of the National Academy of Sciences, [online] 112(18), pp.5649-5654.

Available at: $<$

https://dx.doi.org/10.1073\%2Fpnas.150

3141112/> [Accessed 2 March 2021].

Vidovic, N. and Vidovic, S., (2020).

Antimicrobial Resistance and Food

Animals: Influence of Livestock

Environment on the Emergence and

Dissemination of Antimicrobial

Resistance. Antibiotics, [online] 9(2), p.52.

Available at:

< https://doi.org/10.3390/antibiotics902

0052> [Accessed 6 March 2021].

Vijay, D., Bedi, J., Dhaka, P., Singh, R.,

Singh, J., Arora, A. and Gill, J., (2021).

Knowledge, Attitude, and Practices

(KAP) Survey among Veterinarians, and

Risk Factors Relating to Antimicrobial

Use and Treatment Failure in Dairy

Herds of India. Antibiotics, [online] 10(2),

p.216. Available at:

$<$ https://doi.org/10.3390/antibiotics100

20216> [Accessed 6 February 2021].

Wang, Y., Zhao, Y., Xue, F., Nan, X., Wang,

H., Hua, D., Liu, J., Yang, L., Jiang, L.

and Xiong, B., (2020). Nutritional value,

bioactivity, and application potential of
Jerusalem artichoke (Helianthus

tuberosus L.) as a neotype feed

resource. Animal Nutrition, [online] 6(4),

pp.429-437. Available at:

$<$ https://doi.org/10.1016/j.aninu.2020.0

$\underline{9.001}>$ [Accessed 3 February 2021].

Wittum, T., (2012). The Challenge of

Regulating Agricultural Ceftiofur Use To

Slow the Emergence of Resistance to

Extended-Spectrum

Cephalosporins. Applied and Environmental

Microbiology, [online] 78(22), pp.7819-7821.

Available at:

$<$ https://dx.doi.org/10.1128\%2FAEM.0

1967-12> [Accessed 4 March 2021].

World Animal Health Organization (OIE).

(2021). Member countries: OIE. [online]

Available at:

$<$ https://www.oie.int/about-us/our-

members/member-countries/>

[Accessed 8 March 2021].

World Animal Health Organization (OIE), (2017). Critically important antimicrobials for buman medicine. [online] Geneva: World Health Organization. Available at: $<$ https://apps.who.int/iris/bitstream/ha ndle/10665/255027/9789241512220eng.pdf;jsessionid $=$ BB0B069684AEDB7 CB1583E488E1460CC? sequence $=1>$ [Accessed 4 March 2021].

World Animal Health Organization

(OIE). Responsible and prudent use of antimicrobials. [online] Available at: <https://www.oie.int/en/for-themedia/amr/prudent-and-responsibleuse/ $>$ [Accessed 8 January 2021].

World Health organization (WHO). (2018). Jordan: National action plan for combating antimicrobial resistance in the Hashemite 
Kingdom of Jordan. [online] Available at:

$<$ https://www.who.int/publications/m/i tem/jordan-national-action-plan-forcombating-antimicrobial-resistance-inthe-hashemite-kingdom-of-jordan> [Accessed 8 March 2021].

World Health Organization (WHO). (2019). WHO releases the $2019 \mathrm{AW}$ aRe Classification Antibiotics. [online] Available at:

<https://www.who.int/medicines/news/ 2019/WHO_releases2019AWaRe_classifi cation_antibiotics/en/> [Accessed 7 March 2021].

World Health Organization (WHO).

(2020). An update on the fight against antimicrobial resistance. [online] Available at: $<$ https://www.who.int/newsroom/feature-stories/detail/an-update- on-the-fight-against-antimicrobialresistance $>$ [Accessed 8 March 2021]. World Health organization (WHO). (2021). Jordan Country Overview | World Health Organization. [online] Available at: <https://www.who.int/countries/jor/> [Accessed 8 March 2021].

World Health Organization (WHO). Antimicrobial resistance. [online] Available at: $<$ https://www.who.int/topics/antimicro bial_resistance/en/> [Accessed 8 March 2021].

\section{Acknowledgments}

Special thanks to Tempus Foundation /Hungary for the master's degree scholarship. 


\section{APPENDEXES}

\section{Appendix A}

The registered and reregistered veterinary pharmaceutical in Jordan between 2017-2020

\begin{tabular}{|c|c|c|c|c|c|c|c|c|}
\hline \multirow{2}{*}{ Antimicrobial } & \multicolumn{4}{|c|}{ Produced } & \multicolumn{4}{|c|}{ Imported } \\
\hline & 2017 & 2018 & 2019 & 2020 & 2017 & 2018 & 2019 & 2020 \\
\hline \multicolumn{9}{|l|}{ Antibiotic ( Per Oral) } \\
\hline Aminoglycoside & 3 & 4 & 2 & 0 & 1 & 2 & 2 & 0 \\
\hline Cepaholsporin (cefalexin) & 0 & 0 & 0 & 0 & 0 & 1 & 0 & 0 \\
\hline Fosfomycin & 0 & 1 & 1 & 0 & 0 & 0 & 1 & 0 \\
\hline Ionophores & 0 & 0 & 0 & 0 & 0 & 1 & 0 & 2 \\
\hline Lincosamid & 0 & 0 & 0 & 0 & 0 & 0 & 2 & 0 \\
\hline Macrolides & 1 & 6 & 2 & 2 & 4 & 4 & 3 & 5 \\
\hline Penicillin’s & 1 & 3 & 3 & 1 & 3 & 0 & 1 & 3 \\
\hline Phenicol's & 3 & 5 & 3 & 0 & 1 & 0 & 0 & 0 \\
\hline Pleuromutilin's & 0 & 0 & 0 & 0 & 0 & 0 & 0 & 2 \\
\hline Polypeptide & 2 & 3 & 1 & 1 & 2 & 1 & 1 & 1 \\
\hline Quinolones & 2 & 7 & 5 & 1 & 2 & 2 & 3 & 1 \\
\hline Sulfonamides & 3 & 4 & 6 & 4 & 0 & 0 & 1 & 0 \\
\hline Fluoroquinolones & 0 & 0 & & 0 & 0 & 0 & 0 & 0 \\
\hline Tetracycline & 4 & 6 & 2 & 1 & 2 & 0 & 7 & 1 \\
\hline More than one active material & 2 & 10 & 14 & 4 & 3 & 5 & 6 & 0 \\
\hline Percentage per Year & $19.09 \%$ & $32.67 \%$ & $23.35 \%$ & $15.38 \%$ & $16.36 \%$ & $10.66 \%$ & $16.16 \%$ & $16.48 \%$ \\
\hline \multicolumn{9}{|l|}{ Antibiotic (Parental) } \\
\hline Aminoglycoside & 1 & 0 & 1 & 0 & 2 & 0 & 1 & 2 \\
\hline Cephalosporin & 0 & 0 & 1 & 1 & 2 & 1 & 2 & 5 \\
\hline Macrolides & 0 & 0 & 2 & 1 & 5 & 0 & 5 & 2 \\
\hline Penicillin's & 1 & 1 & 0 & 0 & 4 & 0 & 2 & 0 \\
\hline Phenicol's & 0 & 0 & 4 & 0 & 2 & 2 & 2 & 2 \\
\hline Quinolones & 0 & 0 & 3 & 0 & 1 & 2 & 1 & 3 \\
\hline Sulfonamides & 1 & 0 & 1 & 0 & 0 & 0 & 2 & 1 \\
\hline Tetracycline & 1 & 2 & 11 & 0 & 9 & 5 & 9 & 4 \\
\hline More than one active material & 1 & 1 & 3 & 0 & 4 & 3 & 6 & 4 \\
\hline Percentage per year & $4.55 \%$ & $2.67 \%$ & $15.57 \%$ & $2.20 \%$ & $26.36 \%$ & $8.66 \%$ & $17.96 \%$ & $25.27 \%$ \\
\hline \multicolumn{9}{|l|}{ Antibiotic Intramammary ${ }^{1}$} \\
\hline Total & 1 & 0 & 0 & 0 & 0 & 0 & 0 & 0 \\
\hline Percentage per year & $0.00 \%$ & $0.67 \%$ & $1.20 \%$ & $0.00 \%$ & $2.73 \%$ & $0.66 \%$ & $0.00 \%$ & $0.00 \%$ \\
\hline \multicolumn{9}{|l|}{ Antiparasitic } \\
\hline Ectoparasite $^{2}$ & 10 & 15 & 7 & 12 & 1 & 7 & 3 & 3 \\
\hline Anticoccidial $^{3}$ & 0 & 3 & 3 & 3 & 7 & 1 & 2 & 2 \\
\hline Antiprotozoal 4 & 0 & 1 & 1 & 0 & 0 & 0 & 0 & 0 \\
\hline Anthelmintics 5 & 8 & 22 & 15 & 9 & 7 & 15 & 11 & 8 \\
\hline Percentage per year & $16.36 \%$ & $27.33 \%$ & $15.57 \%$ & $26.37 \%$ & $13.64 \%$ & $15.33 \%$ & $9.58 \%$ & $14.28 \%$ \\
\hline \multicolumn{9}{|l|}{ Alternative to antibiotics ${ }^{6}$} \\
\hline Percentage per year & $0.00 \%$ & $1.33 \%$ & $0.60 \%$ & $0.00 \%$ & $0.91 \%$ & $0.00 \%$ & $0.00 \%$ & $0.00 \%$ \\
\hline
\end{tabular}

Note. The following are the main active material of the mentioned pharmaceutical product:

${ }^{1}$ Cefalonium, Lincomycin hydrochloride and Neomycin sulfate, Benzathine and Ampicillin trihydrate, Cefalexin monohydrate and Gentamycin sulphate, Oxytetracycline and Neomycin.

${ }^{2}$ Afoxolaner, Milbemycin oxime, Clopidol, Fenvalarate, Permethrin, Fipronil, Lambda cyhalothrin Flumethrin, Cyromazin, Alphacypermethrin, Imidacloprid, Organophosphates,Amitraz.

${ }^{3}$ Clopidol, Narasin, Narasin-Nicarbazin, Diclazuril, toltrazuril, Sulphaquinoxaline

${ }^{4}$ Diminazen

5 Ivermectin, Eprinomectin, Rafoxanide, Oxyclozanide, Tinidazole, Netobimin, Oxfendazole, Flubendazole, Amprolium, Albendazole, Levamisole, Tetramisole, Fenbendazole.

${ }^{6}$ Thymol, Menthol, Eucalyptus oil and Artichoke Extract 


\section{Appendex B}

\section{The study questionnaire}

$$
\begin{aligned}
& \text { زميلاتي و زمانئي، } \\
& \text { أود أن أدعوكم لاستكمال هذا الاستبيان .الغرض من هذا المسح هو تقييم دور الأطباء البيطريين الأردنيين في }
\end{aligned}
$$

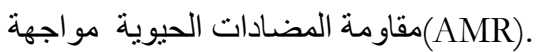

$$
\begin{aligned}
& \text { يرجى ملاحظة أن بالاستبيان لن يذكر اسم المشارك و أن مشاركتكم طو عية تمامًا ولكم كافة الحرية في رفض النه }
\end{aligned}
$$

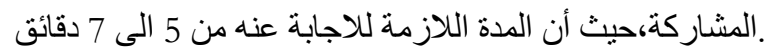

$$
\begin{aligned}
& \text { ولكم جزيل الثكر }
\end{aligned}
$$

Dear colleagues,

I would like to invite you to participate in this survey. The purpose of this survey is to evaluate the role of Jordanian veterinarians in tackling antimicrobial resistance (AMR).

Please note that the survey is anonymous and your participation is entirely voluntary and you are free to decline to participate in this survey. As well as the estimated time to answer it is from 5-7 minutes.

Thank you

The study questionnaire:

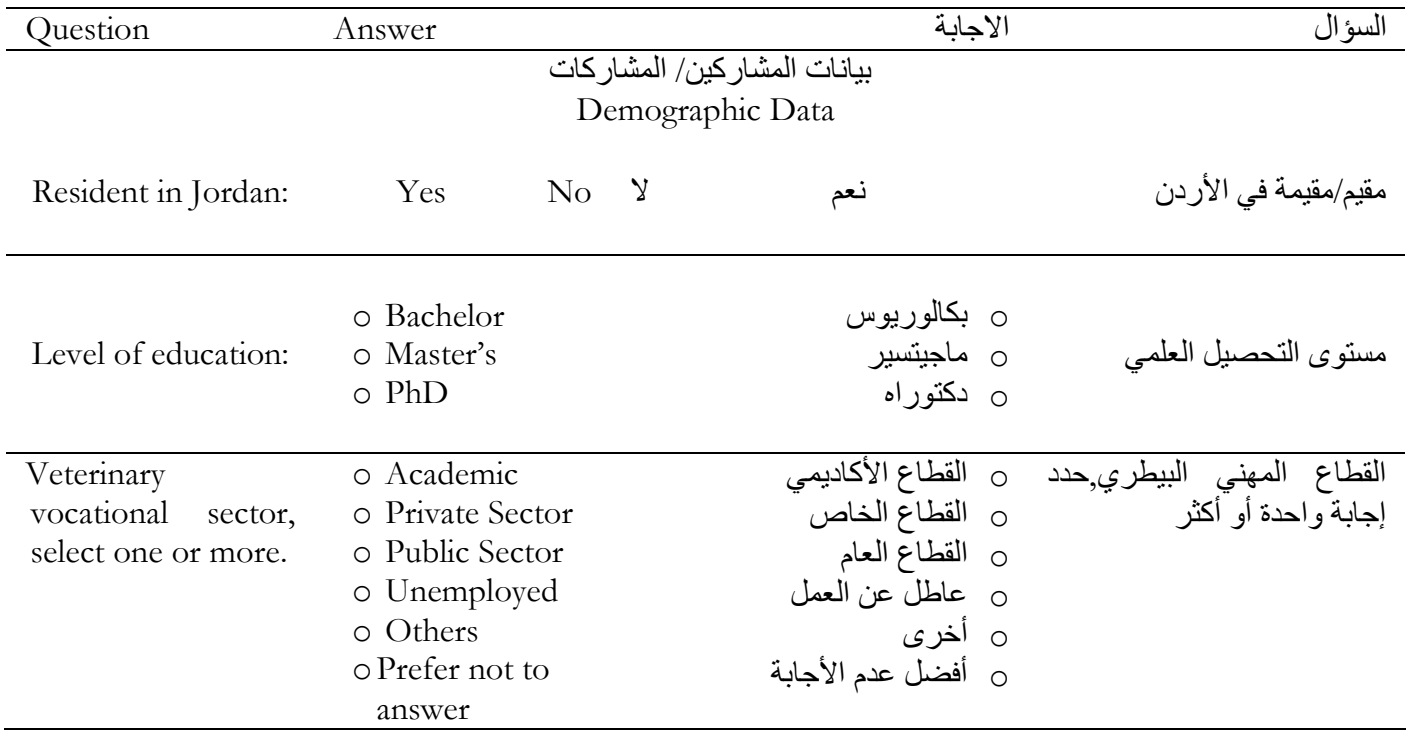




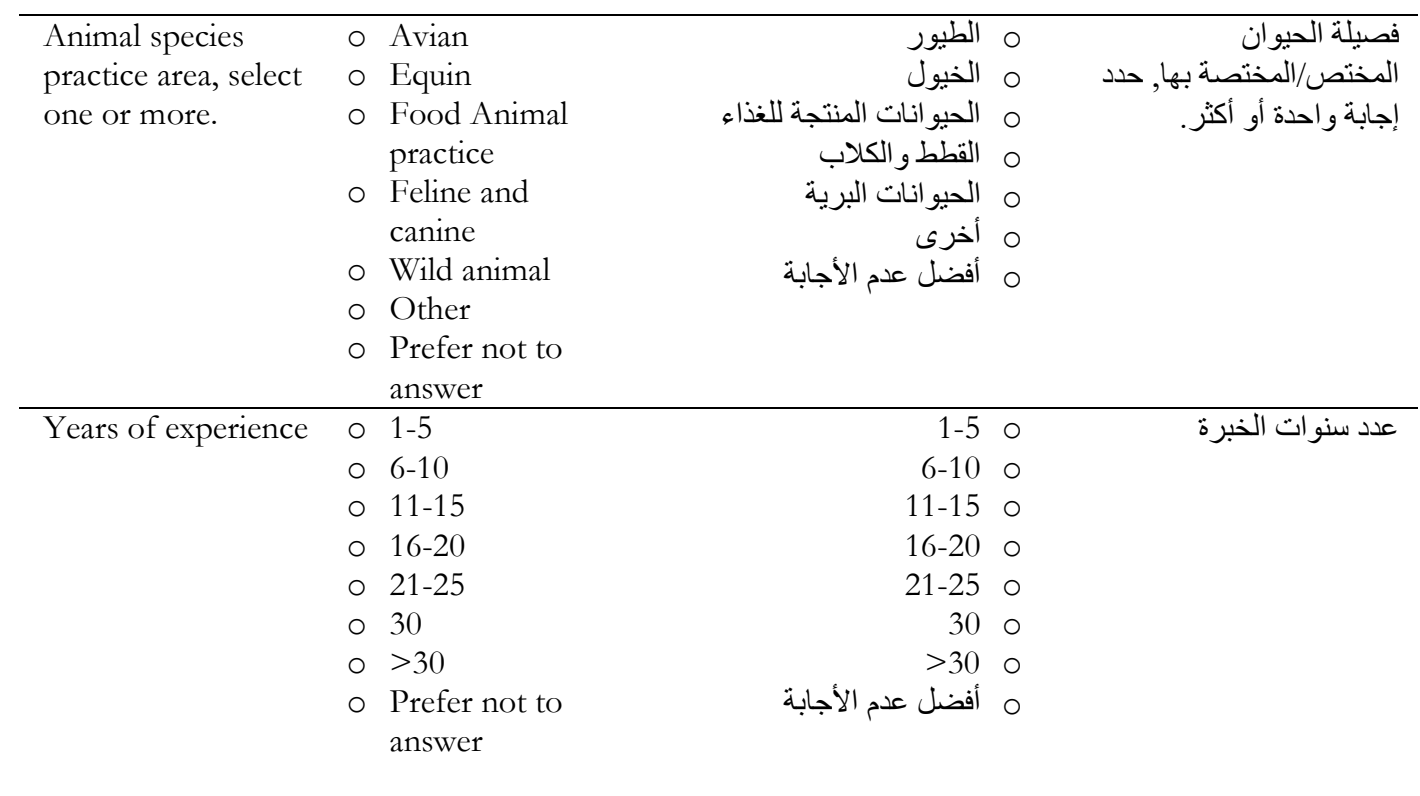

\begin{tabular}{|c|c|c|c|}
\hline \multicolumn{4}{|c|}{$\begin{array}{l}\text { الدور المعرفي للاظباء البيطريين الأردنيين في مواجهة مشكلة مقاومة المضادات الحيوية knowledge in tackling antimicrobial resistance } \\
\text { The role of Jordanian veterinarians knowled }\end{array}$} \\
\hline $\begin{array}{l}\text { Antimicrobial } \\
\text { resistance (AMR) is } \\
\text { when a microbe } \\
\text { evolves to become } \\
\text { more resistant to } \\
\text { antimicrobial which } \\
\text { previously could } \\
\text { treat it. } \\
\text { Antimicrobial } \\
\text { include antibiotics, } \\
\text { which kill or inhibit } \\
\text { the growth of } \\
\text { bacteria. }\end{array}$ & $\begin{array}{ll}\circ & \text { Agree } \\
\circ & \text { Nuetral } \\
\circ & \text { Disagree } \\
\circ & \text { Prefer not to } \\
& \text { answer }\end{array}$ & O & 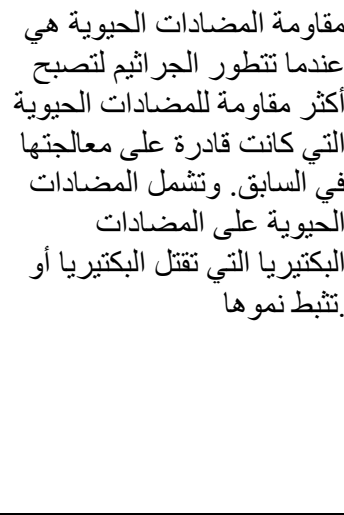 \\
\hline $\begin{array}{l}\text { Use of veterinary } \\
\text { medicinal products, } \\
\text { including } \\
\text { antimicrobial } \\
\text { agents, is essential } \\
\text { for protecting } \\
\text { animal health and } \\
\text { welfare, and } \\
\text { contributes to food } \\
\text { safety and public } \\
\text { health. }\end{array}$ & $\begin{array}{ll}\circ & \text { Agree } \\
\circ & \text { Nuetral } \\
\circ & \text { Disagree } \\
\circ & \text { Prefer not to } \\
& \text { answer }\end{array}$ & 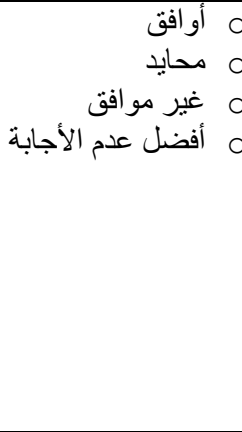 & 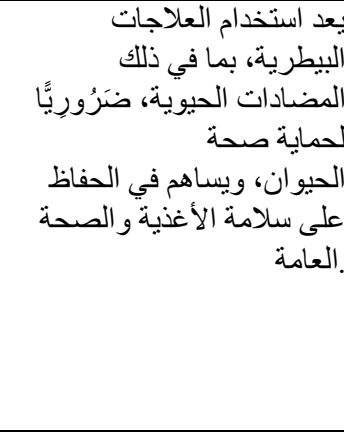 \\
\hline $\begin{array}{l}\text { Microorganisms } \\
\text { represent a pool of } \\
\text { antimicrobial }\end{array}$ & $\begin{array}{ll}\circ & \text { Agree } \\
\circ & \text { Nuetral } \\
\circ & \text { Disagree }\end{array}$ & $\begin{array}{rl} & 0 \\
0 & 0 \\
\text { غحايد افقو افق } & 0\end{array}$ & 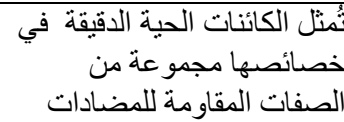 \\
\hline
\end{tabular}




\begin{tabular}{|c|c|c|c|}
\hline $\begin{array}{l}\text { resistance (AMR) } \\
\text { traits in all } \\
\text { ecological niches. }\end{array}$ & $\begin{array}{l}\text { Prefer not to } \\
\text { answer }\end{array}$ & أفضل عدم الأجابة & البيئية البية في جميع الأنماط \\
\hline $\begin{array}{l}\text { The excessive use } \\
\text { of antimicrobial in } \\
\text { livestock (and } \\
\text { aquaculture) will } \\
\text { pose a threat to } \\
\text { people's } \\
\text { livelihoods. }\end{array}$ & $\begin{array}{ll}\circ & \text { Agree } \\
\circ & \text { Nuetral } \\
\circ & \text { Disagree } \\
\circ & \text { Prefer not to } \\
& \text { answer }\end{array}$ & 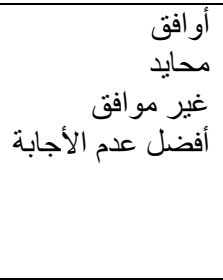 & 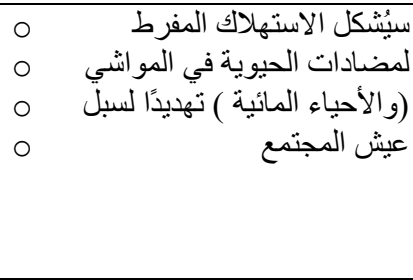 \\
\hline $\begin{array}{l}\text { The increased } \\
\text { contact between } \\
\text { animals and human } \\
\text { beings lead to a } \\
\text { higher risk of } \\
\text { infections and the } \\
\text { cross-transmission } \\
\text { of AMR traits. }\end{array}$ & $\begin{array}{ll}\circ & \text { Agree } \\
\circ & \text { Nuetral } \\
\circ & \text { Disagree } \\
\circ & \text { Prefer not to } \\
& \text { answer }\end{array}$ & 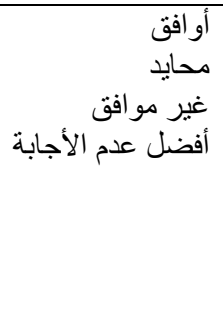 & 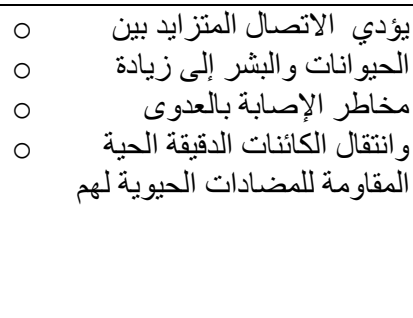 \\
\hline
\end{tabular}

$$
\text { دور ممارسات الأطباء البيطريين الأردنيين في مواجهة مشكلة مقاومة المضادات الحيوية }
$$

The role of Jordanian veterinarians practices in tackling antimicrobial resistance.

للإجابة على الأسئلة من 11 إلى 19 ، يرجى اختيار أفضل مؤشر يعكس ممارساتك في معالجة مقاومة مضادادات الحيوية ، حيث

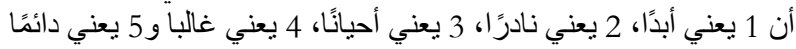

To answer the questions from 11 to 19 , please choose the best indicator that reflects your practices

in tackling antimicrobial resistance, where 1 means never, 2 means rarely, 3 means sometimes ,4 means frequently and 5 means always.

\begin{tabular}{|c|c|c|c|}
\hline $\begin{array}{l}\text { You prescribe } \\
\text { antimicrobial drugs } \\
\text { only when they are } \\
\text { needed to treat an } \\
\text { animal medical } \\
\text { condition after a } \\
\text { clinical } \\
\text { examination, i.e. for } \\
\text { therapeutic } \\
\text { purposes. }\end{array}$ & $\begin{array}{l}0 \\
0 \\
0 \\
0 \\
0\end{array}$ & $\begin{array}{l}1 \\
2 \\
3 \\
4 \\
5\end{array}$ & 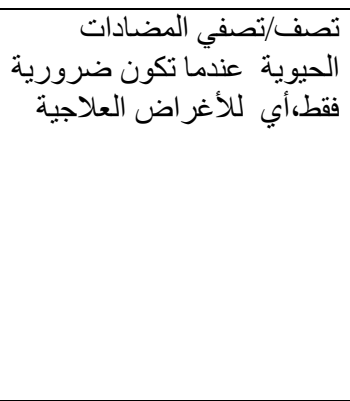 \\
\hline $\begin{array}{l}\text { You recommend } \\
\text { the customers } \\
\text { (farmers, owner..) } \\
\text { to practice good } \\
\text { animal husbandries } \\
\text { such as bio-security } \\
\text { and hygiene. }\end{array}$ & $\begin{array}{l} \\
0 \\
0 \\
0 \\
0\end{array}$ & $\begin{array}{l}1 \\
2 \\
3 \\
4 \\
5\end{array}$ & 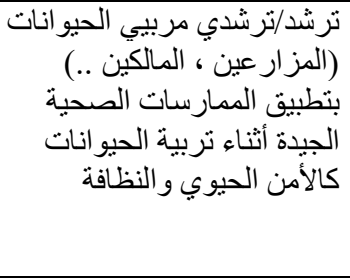 \\
\hline $\begin{array}{l}\text { You make sure that } \\
\text { the specific } \\
\text { antimicrobial } \\
\text { product you use is } \\
\text { the most }\end{array}$ & $\begin{array}{l}0 \\
0 \\
0 \\
0 \\
0\end{array}$ & $\begin{array}{l}1 \\
2 \\
3 \\
4 \\
5\end{array}$ & 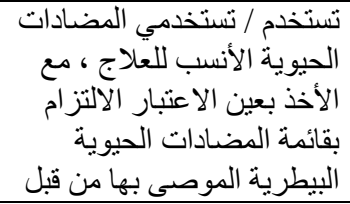 \\
\hline
\end{tabular}




\begin{tabular}{|c|c|c|c|}
\hline $\begin{array}{l}\text { appropriate one for } \\
\text { that purpose, with } \\
\text { taking into } \\
\text { consideration the } \\
\text { World } \\
\text { Organization for } \\
\text { Animal Health OIE } \\
\text { list of antimicrobial } \\
\text { agents of veterinary } \\
\text { importance. }\end{array}$ & & & 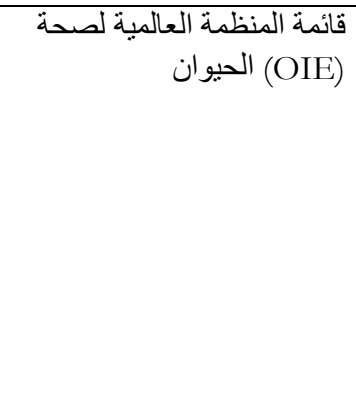 \\
\hline $\begin{array}{l}\text { You administer to } \\
\text { the patient the } \\
\text { correct dose with } \\
\text { the correct } \\
\text { frequency and } \\
\text { duration, by an } \\
\text { appropriate route } \\
\text { and treatment } \\
\text { protocol } \\
\text { considering the } \\
\text { withdrawal period. }\end{array}$ & & $\begin{array}{l}1 \\
2 \\
3 \\
4 \\
5\end{array}$ & 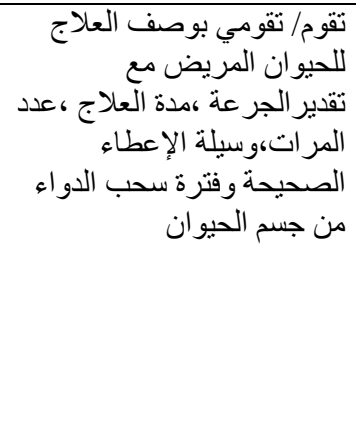 \\
\hline $\begin{array}{l}\text { You recommend } \\
\text { the customer } \\
\text { (farmers, owners...) } \\
\text { to wash their hands } \\
\text { frequently after } \\
\text { dealing with } \\
\text { animals. }\end{array}$ & $\begin{array}{l}0 \\
0 \\
0 \\
0 \\
0\end{array}$ & $\begin{array}{l}1 \\
2 \\
3 \\
4 \\
5\end{array}$ & 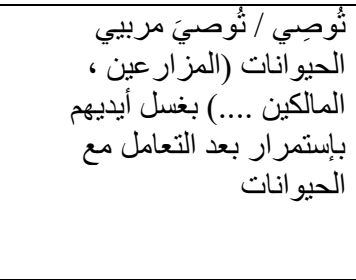 \\
\hline $\begin{array}{l}\text { You explain to the } \\
\text { customer's } \\
\text { (farmers, } \\
\text { owners...) that } \\
\text { antimicrobial are } \\
\text { not our first choice, } \\
\text { and the alternatives } \\
\text { to veterinary } \\
\text { antimicrobial are } \\
\text { also effective. }\end{array}$ & $\begin{array}{l}0 \\
0 \\
0 \\
0 \\
0\end{array}$ & $\begin{array}{l}1 \\
2 \\
3 \\
4 \\
5\end{array}$ & 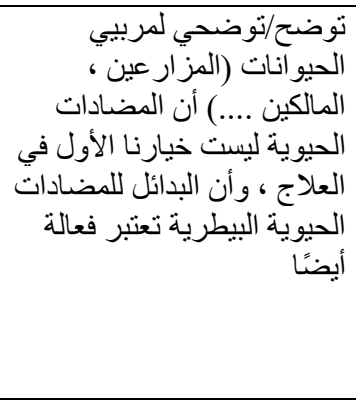 \\
\hline $\begin{array}{l}\text { You committed to } \\
\text { empowering the } \\
\text { customers (farmers, } \\
\text { owners...) to } \\
\text { reduce reliance on } \\
\text { antimicrobial with } \\
\text { at least equal, or } \\
\text { improved, animal } \\
\text { health, welfare ,and } \\
\text { profitability. }\end{array}$ & $\begin{array}{l}0 \\
0 \\
0 \\
0 \\
0\end{array}$ & $\begin{array}{l}1 \\
2 \\
3 \\
4 \\
5\end{array}$ & 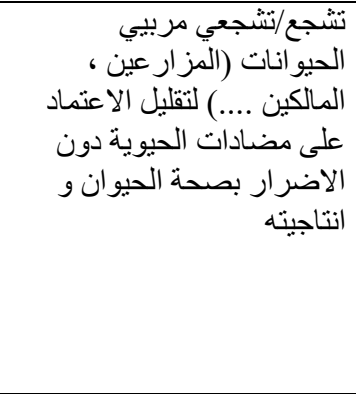 \\
\hline
\end{tabular}




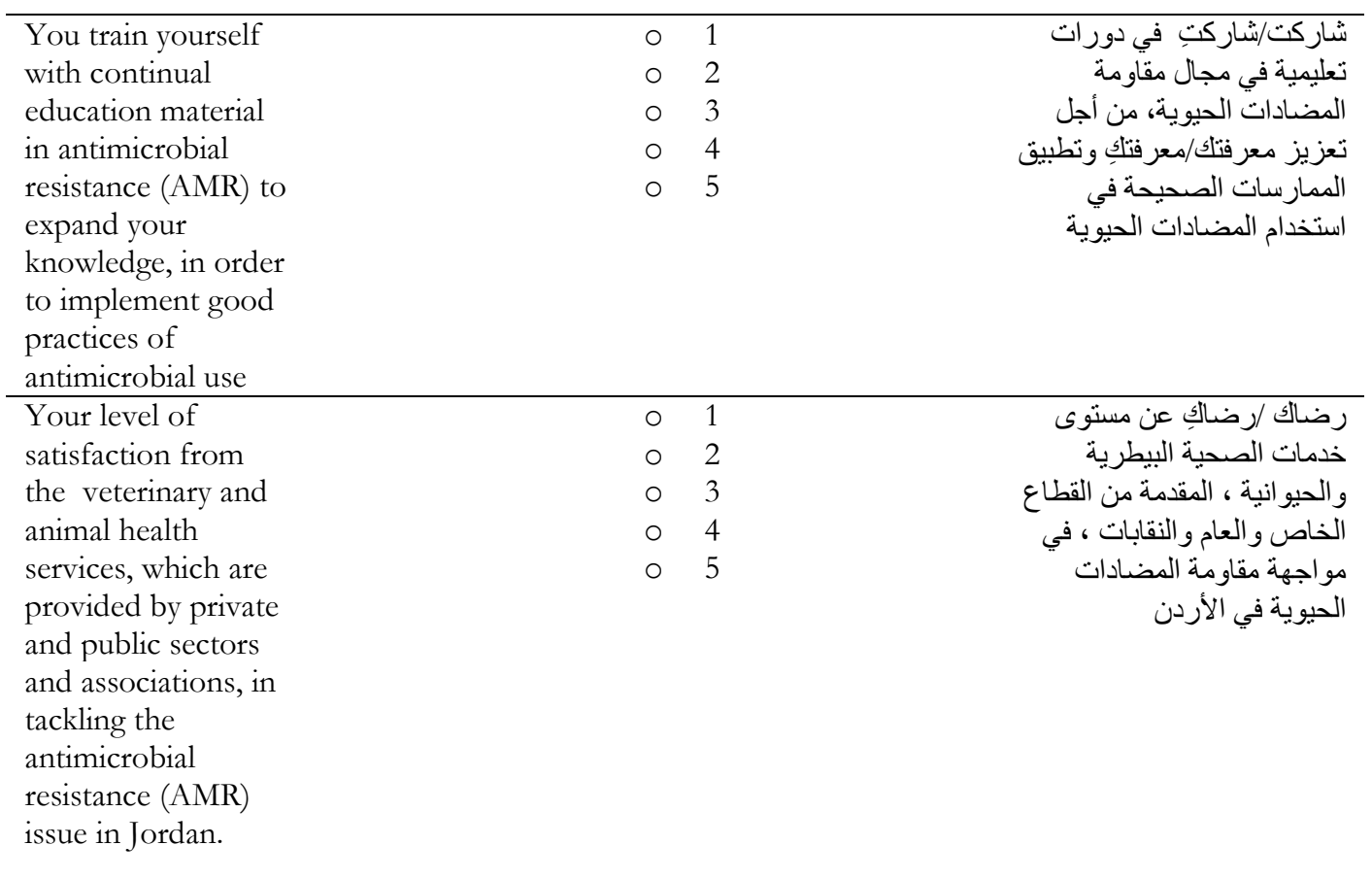

التحديات التي تو اجه الأطباء البيطريين الأردنيين في مواجهة خطر مقاومة المضادات الحيوية

Challenges that face the Jordanian veterinarians in tackling Antimicrobial resistance (AMR).

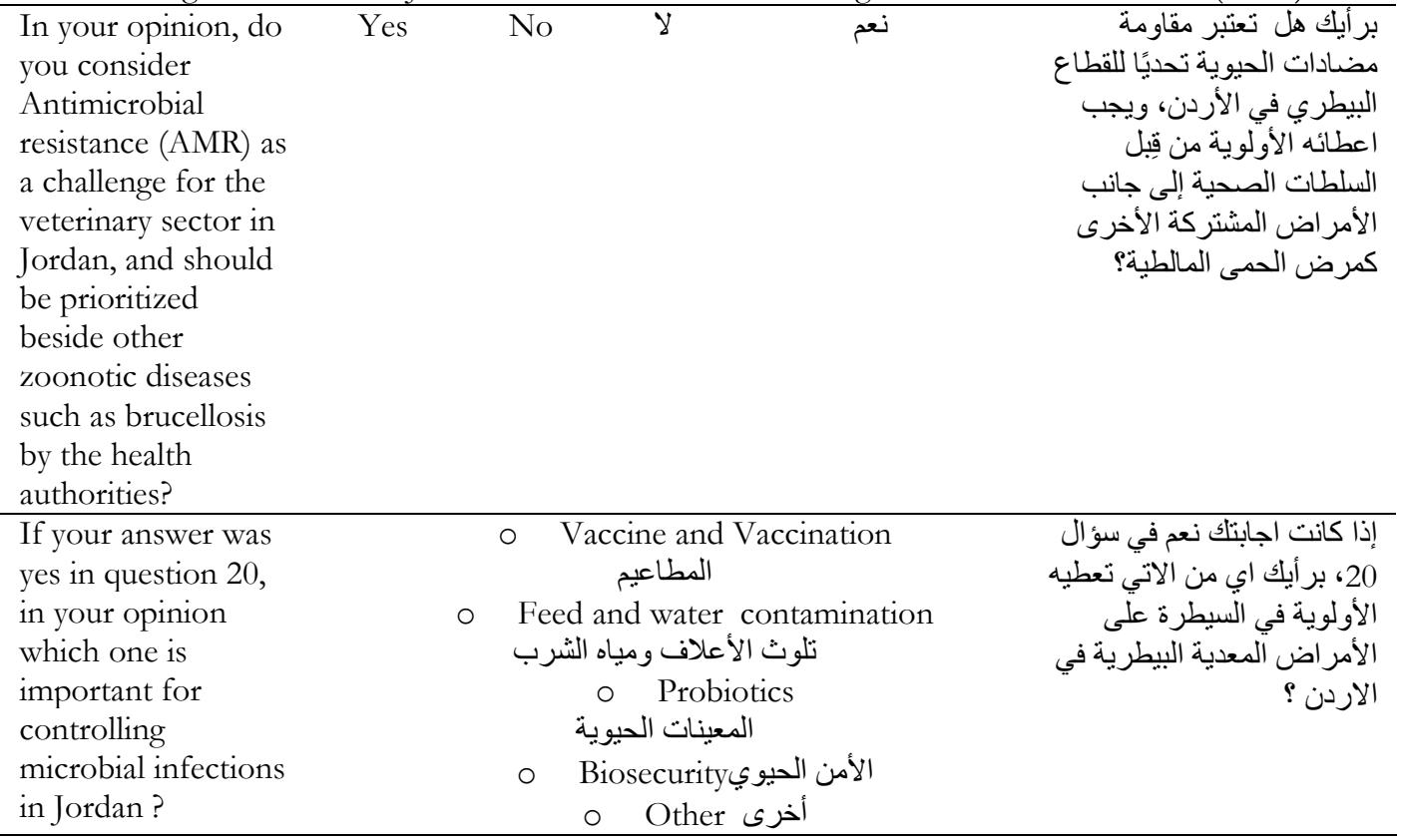




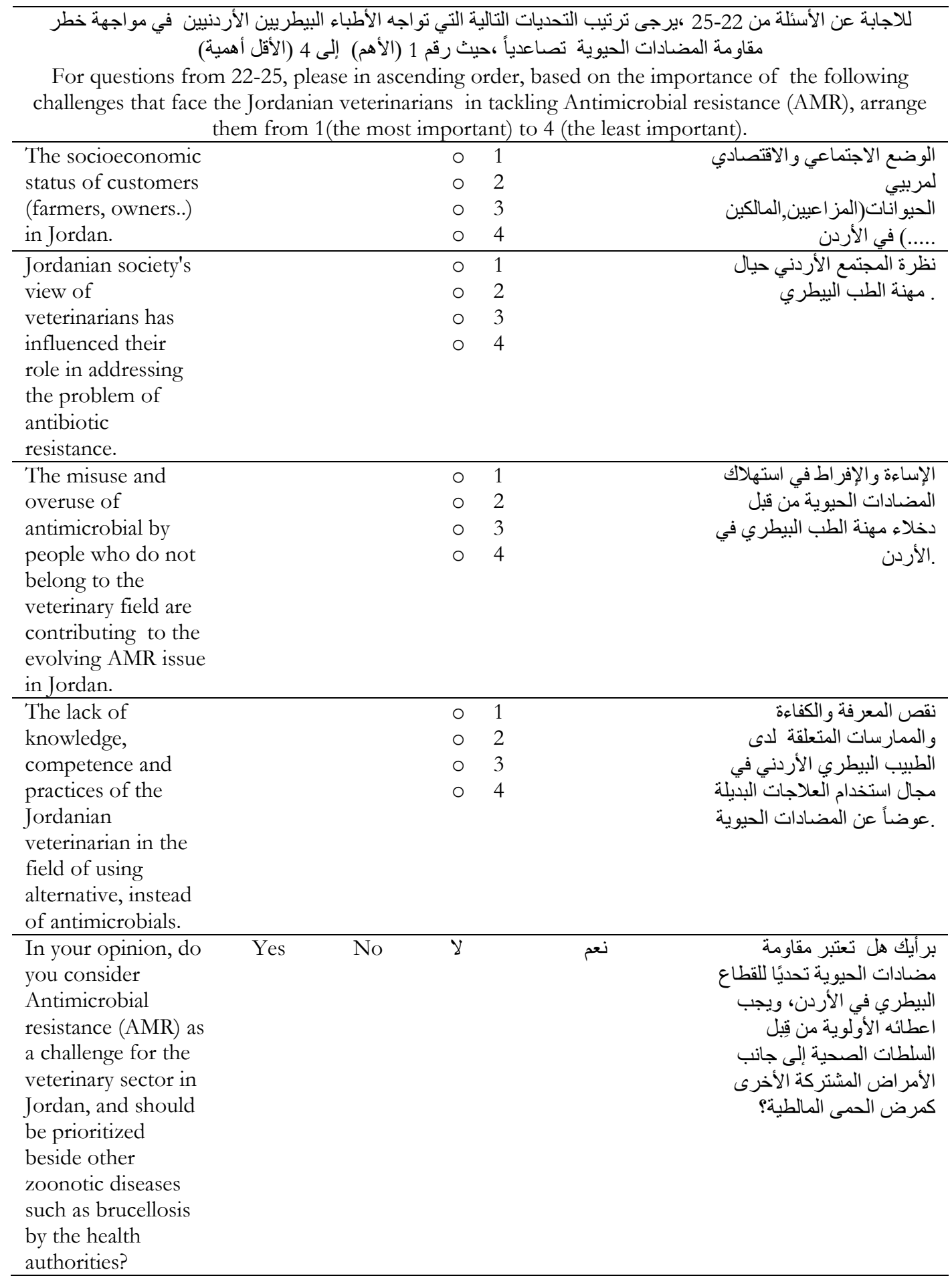




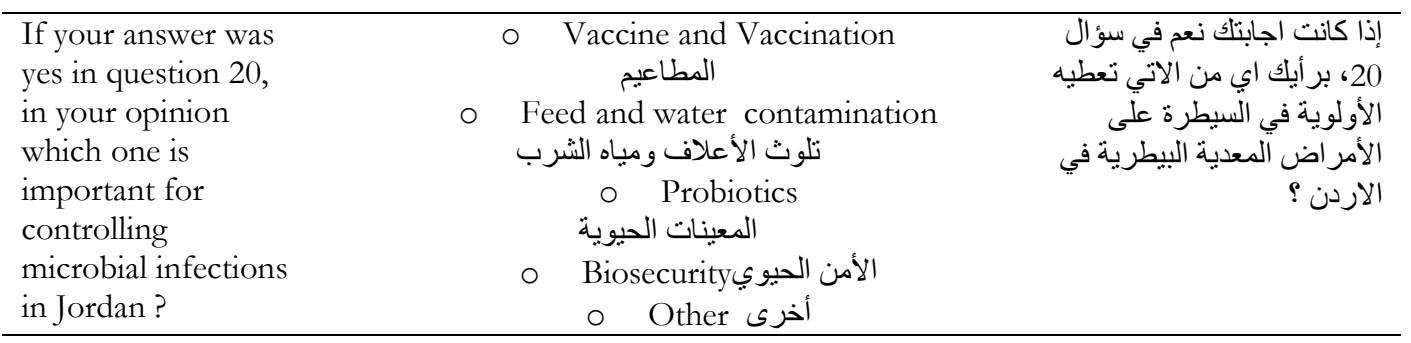

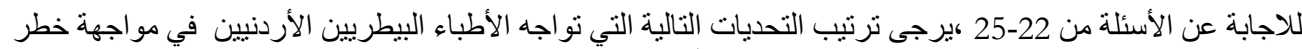

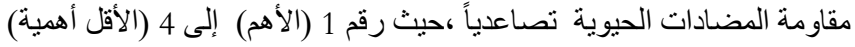

For questions from 22-25, please in ascending order, based on the importance of the following challenges that face the Jordanian veterinarians in tackling Antimicrobial resistance (AMR), arrange them from 1 (the most important) to 4 (the least important).

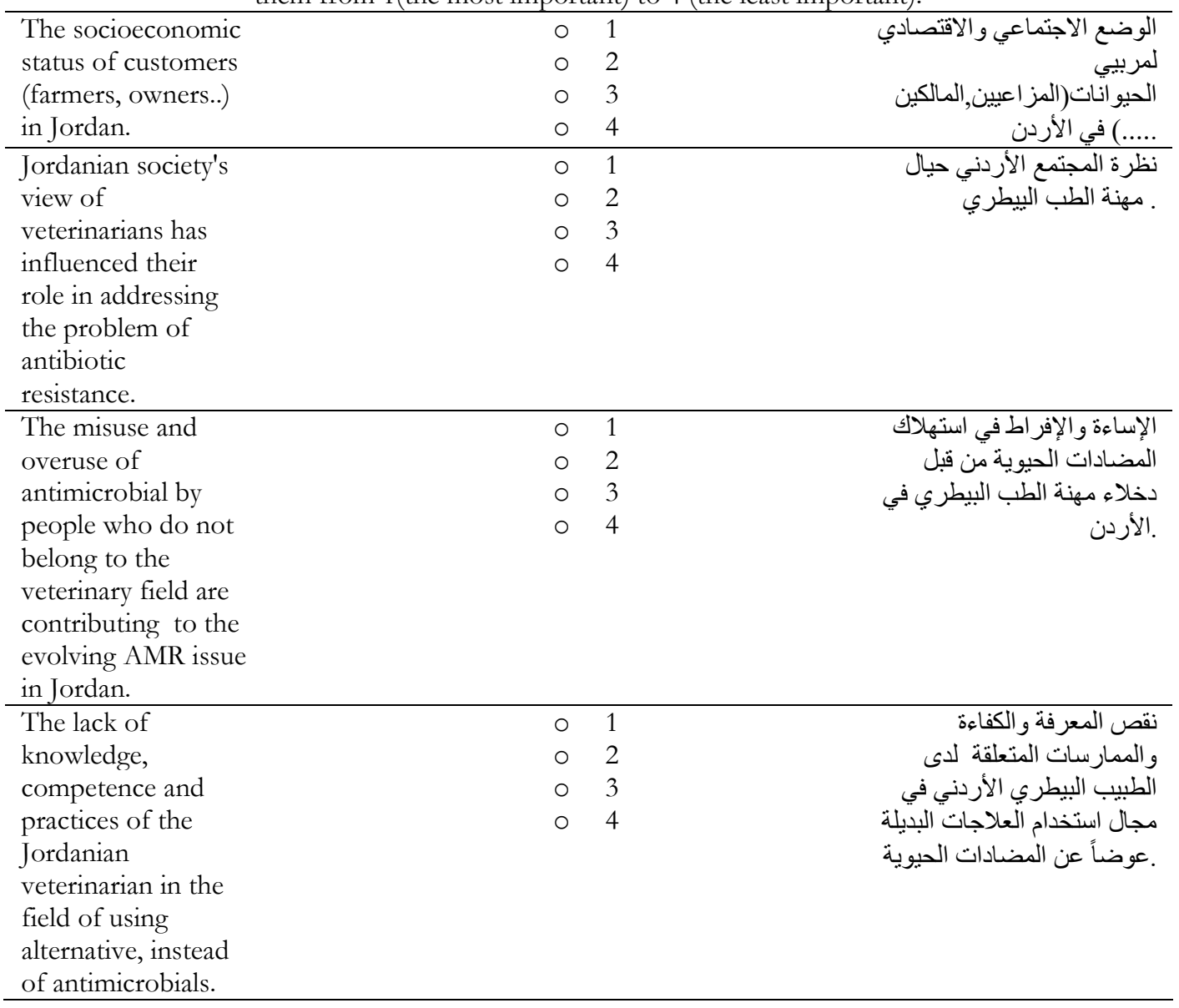

